\title{
Role of Silviculture in the Formation of Norway Spruce Forests along the Southern Edge of Their Range in the Central Russian Plain
}

\author{
Tatiana Chernenkova ${ }^{1, *(\mathbb{D})}$, Ivan Kotlov ${ }^{2}$, Nadezhda Belyaeva ${ }^{1}$, Elena Suslova ${ }^{3}$, \\ Olga Morozova $^{1}$, Olga Pesterova ${ }^{4}$ and Maria Arkhipova ${ }^{5}$ \\ 1 Institute of Geography of the Russian Academy of Sciences, Staromonetniy Pereulok 29, \\ 119017 Moscow, Russia; n.vin@mail.ru (N.B.); olvasmor@mail.ru (O.M.) \\ 2 A.N. Severtsov Institute of Ecology and Evolution of the Russian Academy of Sciences, Leninsky Ave, 33, \\ 119071 Moscow, Russia; ikotlov@gmail.com \\ 3 Biogeography Department of Geography Faculty, M.V. Lomonosov Moscow State University, \\ Leninskie Gory, 119991 Moscow, Russia; lena_susl@mail.ru \\ 4 OOO Forest Engineering Company, 197198 St. Petersburg, Russia; olga1hbg@yandex.ru \\ 5 Sergeev Institute of Environmental Geoscience of the Russian Academy of Sciences, Ulansky Pereulok 13, \\ Building 2, 101000 Moscow, Russia; masha-a@yandex.ru \\ * Correspondence: chernenkova50@mail.ru; Tel.: +7-916-706-52-65
}

Received: 15 May 2020; Accepted: 16 July 2020; Published: 20 July 2020

\begin{abstract}
East European forests dominated by Norway spruce (Picea abies (L.) H. Karst.) in the broad-leaved-coniferous zone should be considered as secondary communities formed under the influence of centuries-long activities (logging, fires and planting) and extended outside their natural range. The study raises an issue-how stable is the current state of Norway spruce forests in the center of the Russian plain and what is the effect of silviculture on the forest cover of the large urban agglomeration - the Moscow Region? Current study is based on multidisciplinary research and consequently concerns the age dynamics of spruce plantation forests, the species and typological diversity of mature spruce forests and spatial pattern of spruce forests along the south edge of their range. The composition and structure of Norway spruce plantations have been studied for various age classes and compared with mature natural spruce forests and pine plantations on the basis of field data. Remote sensing data and modeling approach were applied to estimate the spatial structure of spruce forests. It is found that mature plantations (over 80 years) become similar to natural forests in terms of structure and composition. The relationship between the distribution of spruce formations and the climatic and geomorphological conditions are confirmed. The proportion of spruce and spruce-aspen/birch communities follows the pattern of zones-the transition from the coniferous and broad-leaved forest zone to the broad-leaved forest zone. Despite the significant anthropogenic impact and the high proportion of plantations in the composition of Norway spruce forests (about $60-80 \%$ ), their floristic and typological diversities correspond to such properties of zonal broad-leaved-coniferous communities. Over-matured plantations can provide valuable habitats for the re-establishment of native typological diversity. This makes it possible to use silviculture stands as an accelerated alternative to the natural recovery of disturbed habitats.
\end{abstract}

Keywords: Norway spruce; silviculture; plantation forests; phytocoenotic approach; Moscow Region; Russian plain; spatial modeling 


\section{Introduction}

Norway spruce (Picea abies (L.) H. Karst.) is one of the main forest species in Europe in terms of distribution and economic significance [1]. Norway spruce is widely used in silviculture since the 19th century [2] due to easy planting and subsequent care, as well as due to high biomass productivity. Along with pine, it has low cost of planting. However, opposed to pine, ungulates cause minor damage to spruce. Spruce silviculture stands substitute natural forests beyond its natural range in particular in Central Europe [3,4]. Norway spruce was introduced in Denmark, Belgium and Ireland [2]. Spruce plantation forests extend into the broad-leaved forest zone also [5]. Thus, the current composition of temperate forests in Europe is related mainly to silviculture rather than to natural factors [4] and currently, Norway spruce forests along with pine forests, planted in the 18th and 19th centuries, are now turning into mixed stands with the participation of European beech [6]. Natural spruce forests occur only in certain extreme habitats $[7,8]$.

Much attention has mainly been given in the past to investigate the forest stand formation and productivity of plantations due to their resource importance $[9,10]$. The significance of silviculture stands for maintaining biodiversity has recently been a more frequent issue [11-13]. However, the ecological features and stages of groundcover development in forest plantations have not been described in detail $[11,12,14-18]$. There are also studies of the negative impact of silviculture on biodiversity of understorey $[13,19,20]$. Other studies consider that mixed, multistoried (uneven-sized) stands formed by indigenous tree species (the so-called diversity-oriented, nature-oriented or ecologically oriented) provide suitable habitats for native forest species [21-24]. It is proven that plantation forests could provide habitat even for threatened species [13]. The older the plantation, the more native shade-tolerant forest species appear [25]. On the other hand, plant species richness is enhanced in managed forests compared with unmanaged [26], but it depends on the management type and intensity [27]. Altogether, it is considered that monocultures contain fewer or an equal number of species, whereas polycultures contain equal or more species compared to natural forests under similar ecotopic conditions [28-30].

In the European part of Russia, Norway spruce forests cover totally 46 million hectares. In the central part of the East European Plain (the Russian Plain) including regions: Tver, Novgorod, Moscow, Yaroslavl, Smolensk, Nizhny Novgorod, Kaluga, Ivanovo and Mari El Republic the area of spruce forests is 3.56 million hectares [31,32]. Forests of study area have been actively used since the 17th century. It is proven that, currently, almost all forests were the subject of cutting, fire, or agriculture over the past centuries within the study area [33,34]. Recently, the reverse process of overgrowing of abandoned agricultural land is underway $[35,36]$. A great contribution to maintaining the forest cover of the study area is made by the forestry practice $[37,38]$. The intense commercial activity, including silviculture, which is widespread in the study area, has considerably changed the range of zonal spruce and broad-leaved-spruce communities.

The Moscow Region is located in the central part of Eastern Europe (Russia); its area equals 4.58 million hectares, whereas its population is about 8 million people in the Moscow Region and over 12 million people in Moscow (Figure 1a). Currently, in the Moscow Region, according to renowned foresters [39] and old official data, the proportion of spruce forests equals $25 \%$ of the total forest area, the proportion of plantations is about $60-80 \%$ of all spruce forests. The problem of a sustainable forest use for the Moscow Region is extremely acute. The proximity to large urban clusters inevitably leads to the change in the natural properties of forests, although their importance for the city is extremely high.

Despite considerable research experience in the region, for instance, studying the typological diversity of forest communities and their dynamics [40-45], there is no up-to-date information on the structure and composition of forests in the Moscow Region. The datum on biodiversity development during silviculture activities are also insufficient.

Therefore, the south edge of the spruce forests natural range in the broad-leaved-spruce forests zone is important to study in terms of its possible changes and prospects of sustainable growth. Considering the level of anthropogenic impact, the Moscow Region has feasible potential as a case 
study area. The objective of this paper is to assess the input of silviculture in the formation of Norway spruce forests along the south edge of their range within the central Russian Plain (case study the Moscow Region). The multidisciplinary approach included the following tasks. We compared the process of spruce plantation forests maturation with natural spruce forests and with pine plantations. We than studied the current composition of mature spruce forests. Finally, we estimated the spatial structure and the pattern of the edge of spruce forests range within the case study area. Based on the results we proposed a set of general forest management recommendations considering spruce plantation and natural forests.

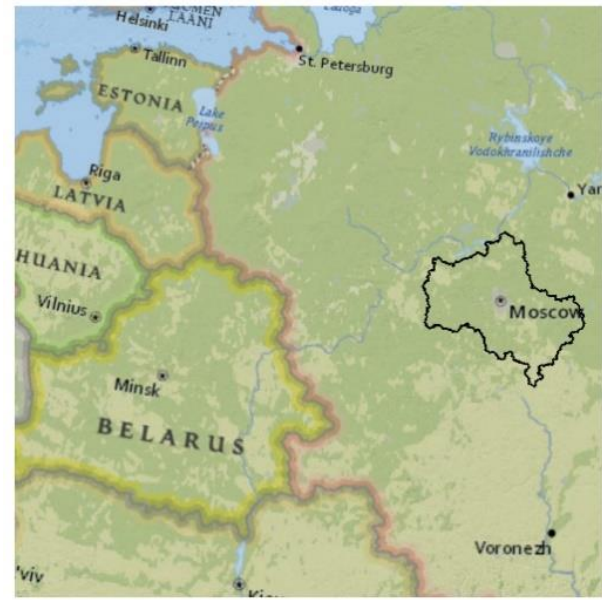

(a)

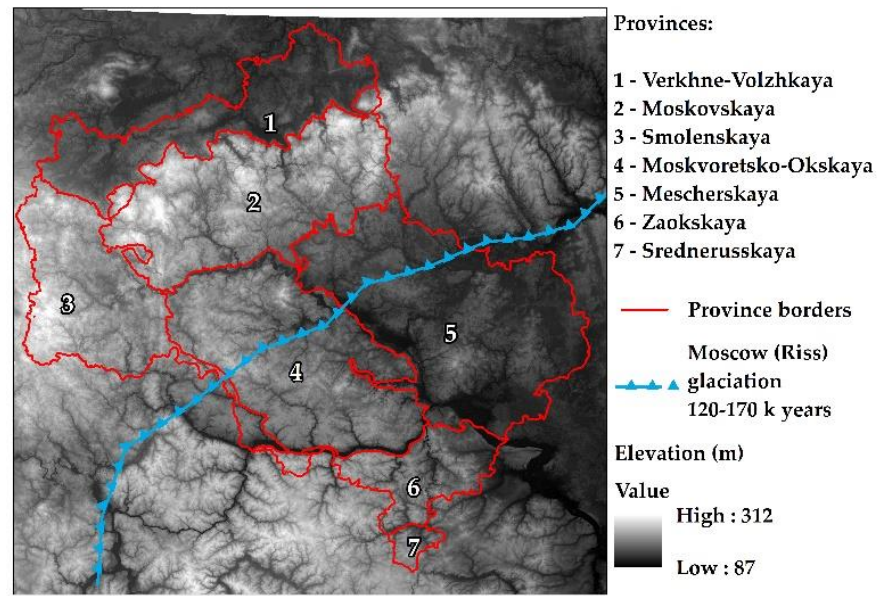

(b)

Figure 1. (a) Location of the study area, (b) physiographic provinces and terrain of the Moscow Region.

\section{Materials and Methods}

\subsection{Study Area, History of Formation and Current Landscape}

The Moscow Region is located in the central part of the East European (Russian) Plain $-35^{\circ} 10^{\prime}-40^{\circ} 15^{\prime}$ East, $54^{\circ} 12^{\prime}-56^{\circ} 55^{\prime}$ North-and covers an area of 4.43 million hectares (less the area of Moscow) (Figure 1a). After expanding its administrative borders in 2012, Moscow became the 6th largest city in the world in terms of area, while the pressure on the region increased considerably due to rapid transport and housing development. The forests of study area which constitute the so-called green belt, are extremely important to maintain the environment and perform social functions taking into account active urban planning in the region, [46-48]. Currently, the forests in the Moscow Region have certain distinctive features:

- considerable recreational pressure related to a high population density;

- limitation on commercial cutting; in accordance with the Forest Code of the Russian Federation, forests of study area are protected (the status of protected forests means that clear cutting is prohibited except in cases of forest damage by disease, insects and fire, when there is a need for clear cutting);

- $\quad$ poor forest sanitation conditions and an unstable environmental situation related to a lack of mandatory forest management actions.

\subsubsection{Physiographical Zoning of Study Area}

The Moscow Region is very diverse in terms of its nature. The region has several important natural and phytogeographical boundaries, related to climatic gradients and heterogeneous moraine and fluvioglacial deposits, formed during glaciations in the Quaternary period. The Moscow Region has seven physiographic provinces: Verkhnevolzhskaya (\#1), Moskovskaya (\#2), Smolenskaya (\#3), 
Moskvoretsko-Okskaya (\#4), Mescherskaya (\#5), Zaokskaya (\#6), and Srednerusskaya (\#7) provinces (Figure 1b) [49,50].

A brief comparison of the climate and landscape features of the physiographic provinces of the Moscow Region is given below. The climate and terrain were compared using the WorldClim [51] and SRTM spatial databases [52]. The comparison of soils and underlying deposits was mainly grounded in the literature [49].

The Moscow Region has a temperate continental climate according to the map of climate zones [53]. The average annual air temperature is $2.7-3.8^{\circ} \mathrm{C}$ and the precipitation is $479-644 \mathrm{~mm}$ (Table A1). In general, there is a latitudinal gradient of temperatures and precipitation. The winter temperature diagram indicates a warming impact of Moscow [54,55]. The elevated provinces in the north and northwest are characterized by a slight decline in summer temperatures compared to the general trend-which is most likely related to the impact of vertical zonal sequence.

The relief of the study area is gently sloping, with heights ranging from 90 to $320 \mathrm{~m}$ a.s.l.; the average height is $174 \mathrm{~m}$ a.s.l., while the average slope is $2.06^{\circ}\left(0^{\circ}-30.9^{\circ}\right)$. Provinces \#1 and \#5 are related to a depression in the crystalline basement and, consequently, to active fluvioglacial flows in the Quaternary period. They have the lowest elevation. The regional subdivide between the rivers Volga and Oka passes through provinces \# 2, \#3 and \#7. These provinces, located at higher elevations, have more rugged relief and steeper slopes.

The gradient change and mosaic of sandy and sandy loam substrates is a crucial factor shaping the edaphic conditions of the Moscow Region. The elevated northern and western provinces of the study area (\#2 and \#3) are dominated by moraine deposits which consist of sandy middle and heavy loam with sand lenses. In lowland, fluvioglacial deposits (provinces \#1, \#4 and \#5) sands with loam interlayers prevail. In the western provinces (\#3 and \#4), nutrient-rich lacustrine and fluvioglacial deposits occur. Loess carbonate loam mantles prevail in the southern part of the area. Subdominant and azonal types of deposits in the study area are silty loam mantles, alluvial in river valleys, swamp, deluvial and aeolian deposits. Sands and sandy loams are poor in nutrients, but they are well-drained and permeable for air. Moraine deposits are nutrient rich; however, they have low permeability and lack drainage. The combination of nutrient content, substrate drainage, groundwater level and other conditions has given rise to a variety of soils, i.e., sod-podzolic, podzolic, swamp-podzolic and grey forest soils.

\subsubsection{Vegetation and Phytogeographical Zoning}

The main part of the Moscow Region is located in the broad-leaved coniferous forest zone in accordance with the phytogeographical zoning layout. The borderwith the broad-leaved forest zone is located in the southern part of the region [56-58]. Zone boundaries, here, are associated with a change in geomorphological conditions determined by the location of the region in relation to the borders of the Moscow glaciation: sandy-loamy plateaus with poor drainage in the west are replaced by well-drained eroded interfluve areas to the east.

The Moscow Region has different types of forests: broad-leaved coniferous forests and spruce subnemoral and boreal forests, as well as broad-leaved forests, the range of which depends on the landscape structure of the territory [59]. The upland forests are mainly mixed spruce and spruce-aspen/birch forests. Broad-leaved forests (oak and lime) cover the elevated surfaces with richer soil habitats, parts of the hill slopes and river terraces. Boreal spruce forest types are not widespread. Pine forests on the uplands are usually plantations.

Silviculture in the Moscow Region started in the first half of the 19th century [60]. It was difficult to promote silviculture and the area of plantations prior to 1917 was small $-14,600$ ha $(1.7 \%$ of the total forest area) [61]. Silviculture was really scaled up only in the second half of the 20th century, arising from the need to tackle a shortage of wood after the war. In the late 1940s, pine plantations were widespread, but starting from the 1960s, there was a transition to spruce plantation, to which primarily ungulates, as well as diseases and insects, cause less damage [62,63]. 
The spruce forests in the region have recently suffered severely from outbreak of European spruce bark beetle (Ips typographus) [40], which is the reason for planting the plantations in the area which was made free after cutting down the trees. Overall, 4-8 thousand hectares of new plantations are created every year [31].

According to the Federal Agency for Forestry, forests including spruce currently account for $25 \%$ of the total forest area in the Moscow Region [31]. In terms of age, young spruce forests (younger than 40 years) prevail 39\%, whereas the forests aged between 40 and 60 years, maturing forests (60-80 years old) and mature and overmatured forests (older than 80 years) cover a similar area, i.e., $23 \%, 22 \%$ and $17 \%$, respectively. Forests older than 80 years are no more considered as plantation forest, therefore, they are not included into plantation forest statistics. The most part of spruce forests presented by plantations the in the region. The opinion of some experts is consistent with this data [39].

\subsection{Methods}

We design the following field work to answer the objectives: (1) compare the process spruce plantation forests maturation with natural spruce forests and with pine plantations, (2) estimate the structure and composition spruce forests in region and (3) classification of field relevés for (4) compiling a subsequent training set for mapping. The field data were collected using a standard methodology [64], in forest sample plots of $400-625 \mathrm{~m}^{2}$. A full species composition and the vertical structure on the site were recorded. The species coverage is given in percent. Layers are designated as follows: A-the tree layer (generative and senile trees), depending on the community structure, this was subdivided into two sublayers (A1 and A2); B-undergrowth (virginile trees-B1) and the shrub layer (virginile and generative shrubs, 1-10 $\mathrm{m}$ high-B2); $\mathrm{C}$-herb and low bushes (including immature trees and bushes lower than $1 \mathrm{~m}$ ); and D-the moss layer. Latin names of vascular plants are given according to $[65,66]$. Latin names of bryophytes are given according to [67-69].

For comparative study of the formation of spruce plantation forests, spruce natural forests and pine plantation forests, we designed the following approach. The main patterns of changes of the composition and structure of spruce plantations for the territory of the southwestern sector of the Moscow Region were studied in the course of age dynamics. As a comparison with spruce plantation forests, data were given on the formation of pine plantation forests, starting from the stage of middle-aged plantations (over 40 years old) as well as with mature natural spruce communities (over 80 years old). We compared ground layer cover and tree layer cover for these three formations.

The data on plantations are based on forest mensuration and on field and satellite data (monodominance, the age of communities and signs of planting in rows). However, judging from our experience, it is quite difficult to figure out, based on the visual features of the structure and composition of mature communities, whether the spruce communities are natural forests or silviculture stands. The information about old plantations was not often available from the forest management authorities. Therefore, the typological composition of mature communities was analyzed regardless of their origin.

To assess the advantages of forming the coniferous plantations of different species, we compared the composition of spruce (73 relevés) and pine plantations (83 relevés) of different age classes [14]. Relevés were made in similar habitat conditions-on uplands with sandy loam soils at sites with an area of (up to) $100 \mathrm{~m}^{2}$. As there were no young pine trees in the researched area, we were not able to monitor the entire cycle of their development (Table 1). To establish the natural origin of mature spruce forests, we used the old forest taxation data.

For assessing the age structure of the silviculture stands, we divided the coniferous species into groups based on their age, according to forest mensuration [70]. To provide a more detailed analysis of the beginning of reforestation, the first age class was divided into two stages. Therefore, seven age stages of forest development were established (Table 1). 
Table 1. Age classes of studied forest communities and number of relevés.

\begin{tabular}{|c|c|c|c|c|c|}
\hline \multirow{3}{*}{ Years } & \multirow{3}{*}{ Age Class } & \multirow{3}{*}{ Age Stage } & \multicolumn{3}{|c|}{ Number of Relevés } \\
\hline & & & \multicolumn{2}{|c|}{ Plantations } & \multirow{2}{*}{$\begin{array}{c}\text { Natural } \\
\text { Spruce Forests }\end{array}$} \\
\hline & & & Spruce & Pine & \\
\hline $1-7$ & \multirow{2}{*}{ I } & 1-Prethicket stage & 5 & & \\
\hline $8-20$ & & 2-Thicket stage & 16 & & \\
\hline $21-40$ & II & 3-Pole stage & 19 & & \\
\hline $41-60$ & III & 4-Maturing stage & 17 & 16 & \\
\hline $61-80$ & IV & 5-Closed-maturing stage & 7 & 11 & \\
\hline \multirow{2}{*}{$\begin{array}{c}81-100 \\
>100\end{array}$} & \multirow{2}{*}{ V } & 6-Mature stage & 7 & 15 & \\
\hline & & 7-Overmature stage & 12 & 44 & 19 \\
\hline Total & & & 83 & 86 & 19 \\
\hline
\end{tabular}

The floristic similarity between the community groups was determined using the Sörensen Index [71]:

$$
C s=2 c /(a+b),
$$

where $\mathrm{c}$ is the number of common species in relevés $\mathrm{A}$ and $\mathrm{B}$, whereas $\mathrm{a}$ and $\mathrm{b}$ are the numbers of species in relevés $\mathrm{A}$ and $\mathrm{B}$, respectively.

To study the composition and the structure of mature spruce communities, we selected relevés with spruce dominating in the community. In spruce forests, we selected relevés where spruce accounted for $75 \%$ and more and in spruce-aspen/birch forests, we selected relevés where the proportions of spruce and aspen/birch were almost equal. Spruce communities are mentioned in 372 relevés, while spruce-aspen/birch communities are included in 237 relevés (the total number is 609). To study the typological structure and composition of spruce communities, we classified field relevés into 2 formations and each formation into 4 association groups. Classification of relevés was performed on a dominant basis, using the matrix principle [72]. Formations of the dominant forest species were identified. By formation, we mean the unit of classification, which is defined by the dominant species of trees. Each formation is represented by communities with different combinations of common dominating species in the understorey. Identification of syntaxa at the level of association groups was performed based on the prevailing ecological and morphological groups of plants in subordinate layers. In the studied area, each spruce and spruce-aspen/birch forest formation is represented by four association groups:

- dwarf shrubs—small herb—green moss (DShG);

- $\quad$ small herb (Sh);

- $\quad$ small herb—broad herb (ShBh);

- broad herb (Bh).

To determine significant differences between the species composition of various classification units (formations and association groups) and between the group means of description coordinates in the NMDS ordination space, the Duncan criterion was used (or Duncan's multiple comparison post-test) [73].

To interpret the ecology of the groups, indirect ordination methods were applied-nonmetric multidimensional scaling (NMDS ordination) in the R software environment [74], using square root transformation, Wisconsin double standardization and the Bray-Curtis distance [75].

During ordination and interpretation of the axes for each description, its Ellenberg's ecological indicator values were calculated [76,77]. Indicators such as light $(\mathrm{L})$, nutrients $(\mathrm{N})$, soil reaction $(\mathrm{R})$ and moisture (M) were calculated using Juice 7.0 [78]. Thus, factor values calculated for each relevé were used to position vectors in the ordination space and to assess the differences between the community 
groups. Differentiation of the four groups was analyzed based on the composition of the subordinate layer $(\mathrm{B}, \mathrm{C}$ and $\mathrm{D})$.

The syntaxa of spruce and spruce-aspen/birch forests are described using groups of indicator, dominant and constant species. The indicator species for association groups were identified using the IndVal method [79]. The species with IndVal > 25\% were considered as indicator ones.

The spruce forests spatial structure was estimated by mapping the association groups. The association groups were mapped using the supervised classification approach in two stages: preparation of a training sample [80-83] and classification. At the first stage, the relevés were filtered and decimated for further use as training sample. The second stage included supervised classification, where the supervised data are environmental variables including a set of multispectral reflectance and coefficients of the digital elevation model. The classification was performed using linear discriminant analysis (LDA) [84]. We used Landsat Level-2 Science Products including surface reflectance bands 1-7 and the spectral indices NDVI, EVI, MSAVI, SAVI, NDMI and NBR [85]. The weather of the Moscow Region is very cloudy except in September and March and it is covered by multiple Landsat scenes. Therefore, we performed mosaicking of images for 5 periods: for Landsat 8: (1) mid-March (2015-2017), (2) mid-May (2015-2018), (3) beginning of July (2014-2016) and (4) mid-September (2014-2018) and for Landsat 5: mid-July (2010-2011). We used SRTM DEM and 12 topographic coefficients: elevation, slope, aspect, RMS error, insolation, Laplacian and convexity (cross-sectional, longitudinal, plan, profile and maximum and minimum convexity) [86]. The total number of environmental variables was 84 . To reduce the impact of intercorrelation between environmental variables, we performed principal component analysis. After removing principal components with eigenvalue $<1$, we obtained 14 principal components for modeling. The recognition quality of LDA was equal to $47 \%$ (including other non-forest land cover classes). The recognition quality for the 8 association groups discussed in current paper varies from $2.9 \%$ to $89.5 \%$ (Table A2).

We demonstrate the example of a site index plot (with an area of 51,000 hectares) in the southwestern part of the Moscow Region, in accordance with forest mensuration data, silviculture stands were digitized and mapped.

\section{Results}

\subsection{Differences in the Organization of Coniferous Plantations in Relation to the Age Structure}

\subsubsection{Formation of Spruce Plantations at Early Stages (1-40 Years)}

In the areas disturbed by logging and preparing soil for planting, the diversity of biotopes determines the floristic richness of communities at the early stages of their development. In young spruce plantations (up to 7 years old), this is manifested within the high cover of the herb-dwarf shrub layer (up to 95\%) and high species saturation of the relevés (Figure 2a,b). This stage (1-7 years) differs most in species composition from both natural spruce forests $(C s=54 \%)$ and older plantations. The initial stages of community development are characterized by a large proportion of weed and meadow-edge species, such as Chamaenerion angustifolium, Hypericum maculatum, Leucanthemum vulgare, Potentilla erecta, Calamagrostis epigeios, etc.

The processes of community development accompanied by canopy closing (Figure 2a) and shading of subcanopy space lead to the gradual elimination of light-demanding species of disturbed habitats. Forest species already present there as well as those introduced from nearby communities (Ajuga reptans, Dryopteris carthusiana, Fragaria vesca, Rubus saxatilis, etc.) start spreading. At the age of 21-40 years, young plantations and some aspen/birch trees reach $14-20 \mathrm{~m}$ in height and the maximum cover of the tree layer and undergrowth is observed, while the cover of the shrub and herb-dwarf shrub layers is at a minimum (Figure 2a,b). At this stage, plantations with a sparse herb layer often develop.

Thus, closing the tree canopy radically transforms the postcutting communities. The canopy begins to shape the structure and composition of the herb-dwarf shrub and moss-lichen layers. Canopy closure changes the climate conditions to less deep freezing of the soil, later thawing, later snow cover 
melting and less warming of the soil and lower air layers during the warm period, which eventually shortens the growing season and weakens the vegetation. The composition and structure of plantation communities becomes gradually similar to the natural forests of the region with age. The impact of spruce leads to age-dependent differences in the structure and floristic composition of the studied plantations. This primarily arises from the morphological and physiological features of the spruce stand. Spruce litter is characterized by a low $\mathrm{pH}$, which leads to the formation of peaty forest floor and coarse humus with an acidic reaction. Together, these features of spruce forests activate podzol formation processes.

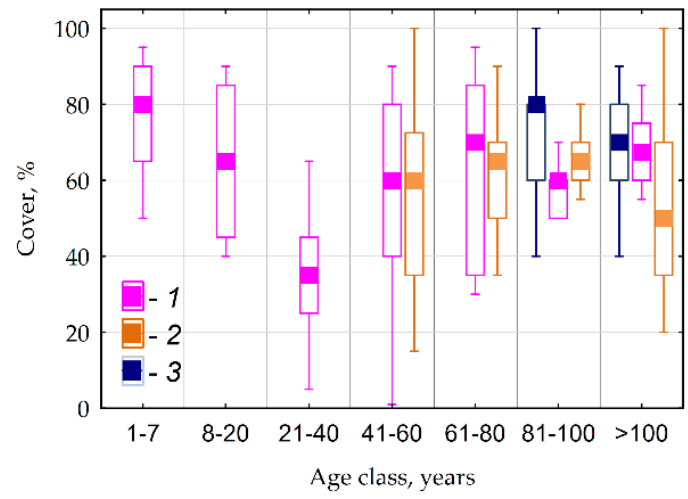

(a)

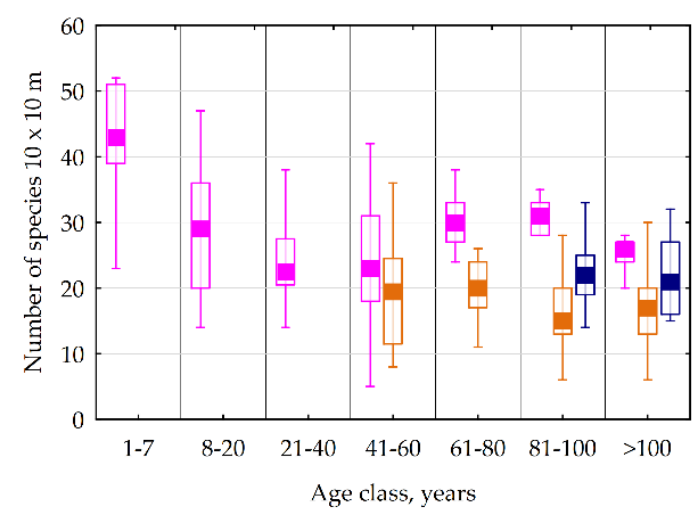

(b)

Figure 2. (a) Box plot of ground layer cover in plantations of different ages, (b) box plot of species diversity of ground layer in plantations of different ages; 1 -spruce plantations; 2 -pine plantations; 3 -native spruce forests. Box-whisker type: median/25 and 75 percentiles/nonoutlier range.

The formation and closing of plantation stand reduce the availability of light and soil moisture, leading to restructuring of the plant community. Analysis of the herb-dwarf shrub layer cover showed that it moderately depends on the cover of layers A and B $(r=0.5)$. A significant downsizing of the herbs and shrubs cover in spruce plantations at the age of 21-40 years is due to the both canopy closure (Figure 3) and competition for resources. It is worthy of note that the species saturation of such plantations is markedly reduced—on average, 24 species per $100 \mathrm{~m}^{2}$ (Figure 2) and the species composition changes significantly compared with earlier stages.

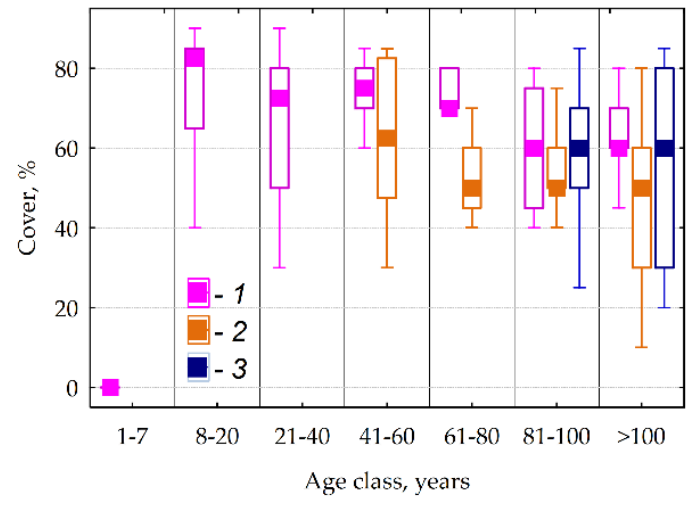

(a)

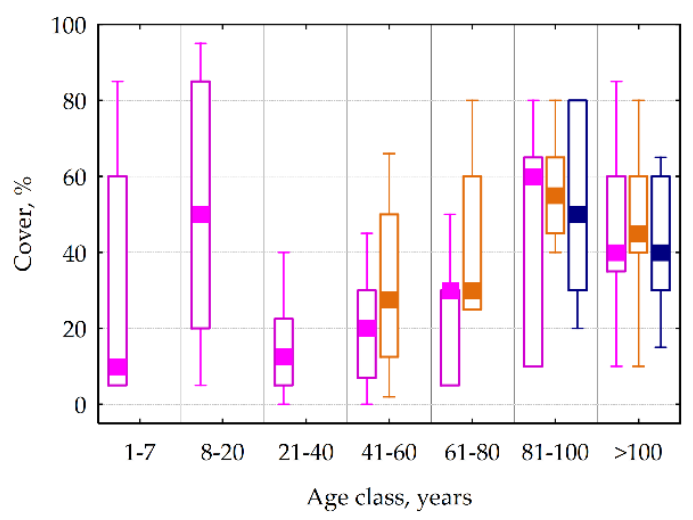

(b)

Figure 3. (a) Box plot of cover of tree layer in plantations; (b) box plot of cover of undergrowth layer for various ages; 1 -spruce plantations; 2 - pine plantations; and 3-native spruce communities. Box-whisker type: median/25 and 75 percentiles/nonoutlier range. 
3.1.2. Comparative Analysis of the Formation of Middle-Aged and Mature Spruce and Pine Plantations (over 40 Years Old)

Further changes in spruce plantations are more related to the community structure than to the floristic composition - the similarity coefficient Cs does not change, starting from the age of 21-40 years. At the age of 41-80 years, the differentiation of the tree layer into sublayers occurs. Small-leaved species (aspen and birch) gradually disappear from the community (if they were not removed mechanically at previous stages during logging and thinning) and spruce starts to dominate in the stand (Figure 4).

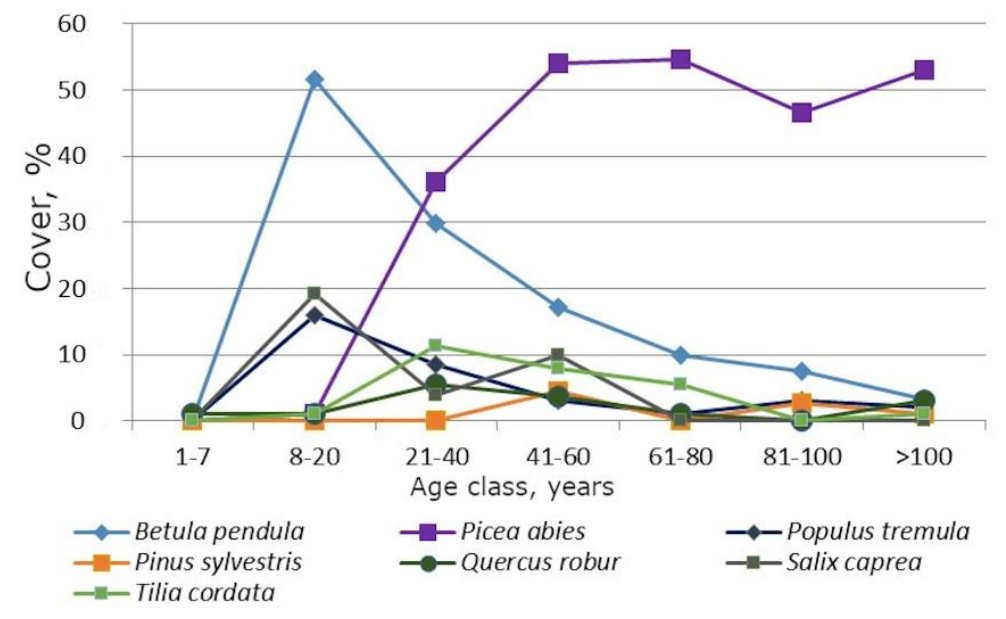

Figure 4. Average cover of canopy species (A1) in various age classes.

When the processes of forest stand fall begin with the formation of windfall gaps, spruce plantations older than 80 years become closer to natural forests in terms of their floristic $(C s=77 \%)$ and structural indicators. The gaps are sometimes occupied by lime, which usually accompanies spruce in forests of natural origin. The cover of shrub and herb layers increases in the gaps.

In mature communities (aged 80 and older), the height of the A1 subcanopy layer ranges between 27 and $33 \mathrm{~m}$. In spruce plantations, it mainly consists of spruce and birch, while aspen occurs more rarely and sometimes, there are broad-leaved species such as oak and lime, but their proportion in the canopy is less than 1\% (4). The proportion of the A2 subcanopy layer in spruce plantations is small (the canopy density is about 15-20\%) and it is not present in a third of all relevés. Most often, it includes spruce trees of silviculture origin, which have low growth rate and birch trees. Regeneration of broad-leaved species is active on some sites.

Comparison of the organization of spruce and pine plantations of more than 40 years old with natural spruce communities revealed special patterns in their composition formation. The canopy density assessment showed that this indicator varies considerably in different communities. Pine plantations have the largest values (Figure 3a), which are related to pine morphological traits. In silviculture pine stands, the average canopy density is 50\%, whereas in natural communities and spruce plantations, the average canopy density is $65 \%$. The communities with regeneration of spruce under the canopy of pine have the highest canopy density.

In general, pine and spruce plantations are able to maintain the canopy species composition of the broad-leaved coniferous forests in the region. In natural forests, the proportion of aspen is slightly larger than in spruce plantations. In pine plantations, aspen did not occur. The proportions of broad-leaved species (lime and oak) are equal in the second subcanopy layer of spruce plantations and natural communities, whereas the proportion of lime is slightly smaller than in natural forests and the proportion of oak is somewhat larger in pine plantations.

The understorey and undergrowth (B layer) were well developed in all the analyzed communities. The cover was almost equal in all those community types. Regeneration of spruce was more active in pine plantations (8\%) and less active in natural spruce forests (4\%). Species such as Corylus avellana, 
Lonicera xylosteum, Viburnum opulus and Sorbus aucuparia are typical of the layer. A comparative analysis of species in the understorey and undergrowth showed that Daphne mezereum, Populus tremula and Viburnum opulus occur more often in natural broad-leaved coniferous forests. Pine plantations are grown in lighter and moister sites with more heliophilous and hydrophilous species such as Padus avium and Rubus idaeus, whereas Frangula alnus and Populus tremula almost do not occur there. The floristic composition of the layer B in spruce plantations is more similar to natural spruce forests than in pine plantations. The broad-leaved species such as Quercus robur and Tilia cordata occur more often in spruce plantations and their average cover is thicker in natural forests. This indicates that the older spruce plantations are closer to the natural zonal spruce forest communities.

With changes in age, under the canopy of plantations, especially pine, there is active regeneration of tree species which grow in the natural community. At the same time, spruce plantations maintain the floristic composition of the herb-dwarf shrub layer, which is closer to the initial composition; however, its regeneration is faster than in pine plantations.

The species of the herb-dwarf shrub layer (C layer) in spruce plantations are closer to natural forests in the region than the species of the layer in pine plantations. Some species occur more often in spruce plantations (Actaea spicata, Carex digitata, Circaea alpina, Impatiens noli-tangere, Luzula pilosa, etc.), while some of them are found only here (Adoxa moschatellina, Coccyganthe flos-cuculi, Daphne mezereum, Sanicula europaea, etc.)—the species included in the Red Data Book of the Moscow Region [87]. In spruce plantations, the number of species is larger, but the herb-dwarf shrub layer is not as thick as in natural spruce forests. It is worthy of note that the floristic similarity index of spruce plantations and both natural forests in the region and pine plantations is also $77 \%$.

In the herb-dwarf shrub layer of pine forests, the species such as Geum rivale and Stellaria nemorum, which grow in moist and damp sites and Athyrium filix-femina, Dryopteris carthusiana and Ranunculus cassubicus and some other forest species that occur on sites with sufficient insolation and moist fertile soils, occur more often than in other communities.

Analysis of the number of vascular plant species showed that their largest number is in spruce plantations (Figure 2b). The number of species in the sampling areas ranges between 26 and 50 for spruce plantations, 15-42 for pine plantations and 22-44 species for natural communities.

Therefore, the research reveals that in the Moscow Region, the number of vascular plant species and bryophytes in the communities of coniferous plantations aged 80 and older is as large as the number of species in natural spruce forests. Mature and overmatured plantations (older than 80) are close to natural forests in terms of their structure and flora. In the case of timely care of planting (regular thinning, etc.), this is also possible at the age of 60 or 70 .

In general, changes in the plant cover in spruce plantations occur faster than in natural secondary succession, as small-leaved species (aspen and birch) do not dominate for a long time.

\subsection{Composition and Structure of Spruce and Spruce-Aspen/Birch Forests of Moscow Region}

Our study demonstrated that it is hard to distinguish between natural or artificial origin of spruce communities when using visual patterns of community structure and composition. The data on old plantation activity often lacks in forest management administrations. In this respect, we analyzed species and typological composition regardless of mature community origin. This approach is substantiated in Section 3.1.

\subsubsection{Typological Structure}

As a result of the ecological and phytocoenotic classification of spruce and spruce-aspen/birch forest communities, we identified 8 association groups, based on the composition of the tree and subordinate layers (Table 2). Representative images of association groups are provided in Figure 5.

To properly analyze the composition of the selected syntaxa at the level of formations and association groups, differences were identified for vegetation combinations of different layers. In particular, the differences between the two formations in the tree layer composition are significant 
according to the Mann-Whitney U-test $(p<0.01)$. Analysis of the composition of the tree layer between the 8 association groups using ANOVA revealed rather weak differences: $F(7595)=3.37, p=0.001$. This could account for the similarity of the tree species composition and the cover of species in the communities of spruce forests (groups 1-4) and spruce-aspen/birch forests (groups 5-8).

When comparing the vegetation composition of the 4 community groups (1-DShG forests, 2-Sh forests, 3-ShBh forests and 4-Bh forests), grouped based on the subordinate layers- C and D, excluding the tree layer, significant differences by the Duncan criterion were observed for all pairs. The value of the F-statistic was also high: $\mathrm{F}(3605)=239.41, p<0.01$.

Furthermore, in general, there were significant differences in the ecological coordinate positions of the relevés when analyzing the total species composition of the 8 association groups: $F(7601)=35.85$, $p<0.01$. Significant differences in pairwise comparison were not confirmed (Duncan test) for the pairs of syntaxa: $1-2,1-5,1-7,2-7,3-8$ and $5-6$. This indicates the similarity of their composition (Table A5).

Thus, based on the composition characteristics of the two formations, the composition of the tree layer will be considered within all 8 association groups. The similarity of the vegetation composition of the subordinate layers of spruce and spruce-aspen/birch forests allows us to analyze the characteristics of the shrub (B2), herb-dwarf shrub (C) and moss (D) layers within the four community groups.

The organization of the spruce and spruce-aspen/birch forests is considered below according to a unified layout.

Table 2. Association groups of spruce and spruce-aspen/birch forests.

\begin{tabular}{|c|c|c|c|}
\hline Formation & \# & Association Group & Number of Relevés \\
\hline \multirow{4}{*}{ Spruce } & 1 & Spruce with birch and pine, DShG & 37 \\
\hline & 2 & Spruce with birch and pine, Sh & 40 \\
\hline & 3 & Spruce with birch, ShBh & 147 \\
\hline & 4 & Spruce with birch, lime and oak, Bh & 148 \\
\hline \multirow{4}{*}{ Spruce-aspen/birch } & 5 & Spruce-aspen/birch with pine, DShG & 32 \\
\hline & 6 & Spruce-aspen/birch, Sh & 22 \\
\hline & 7 & Spruce-aspen/birch, ShBh & 81 \\
\hline & 8 & Spruce-aspen/birch with lime and oak, Bh & 102 \\
\hline
\end{tabular}

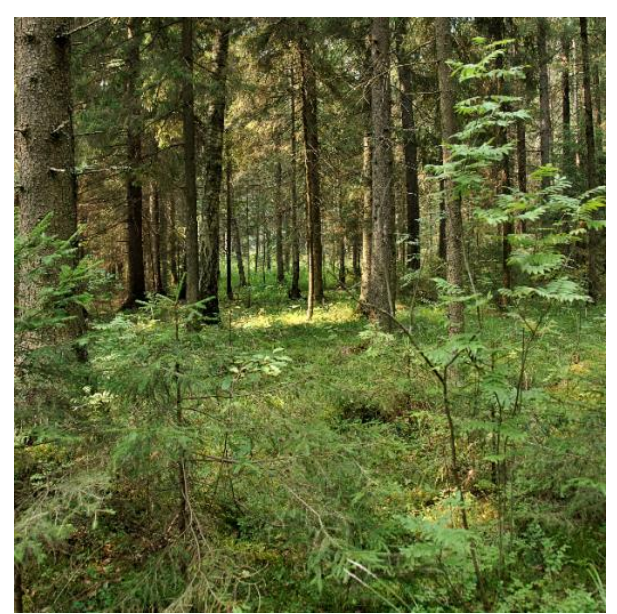

(a)

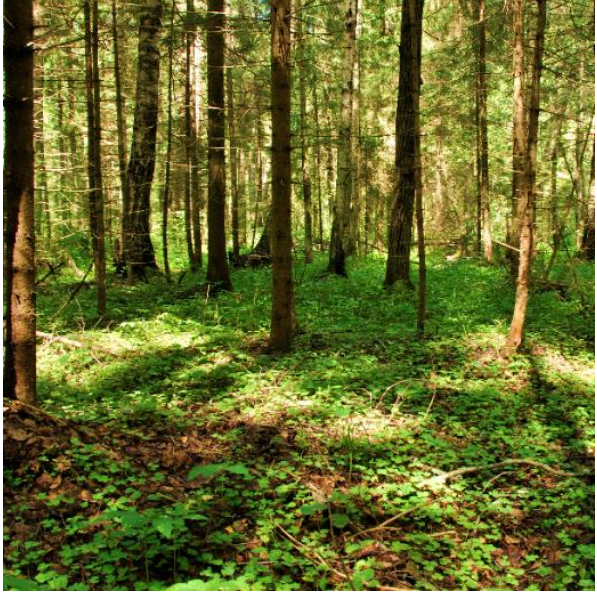

(b)

Figure 5. Cont. 


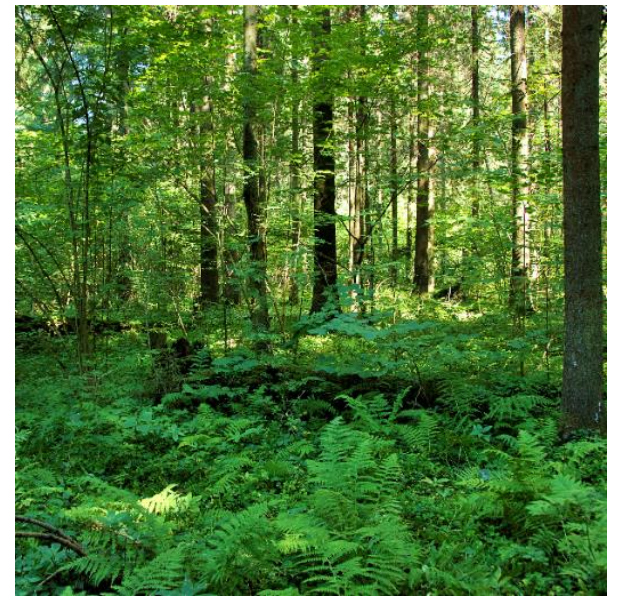

(c)

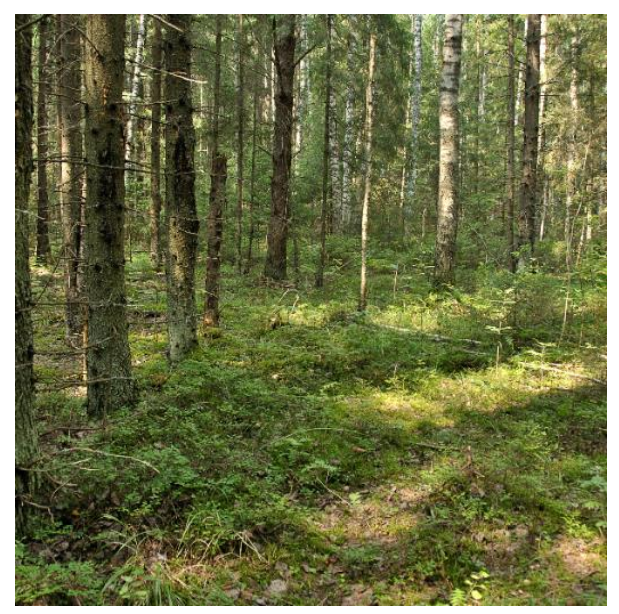

(e)

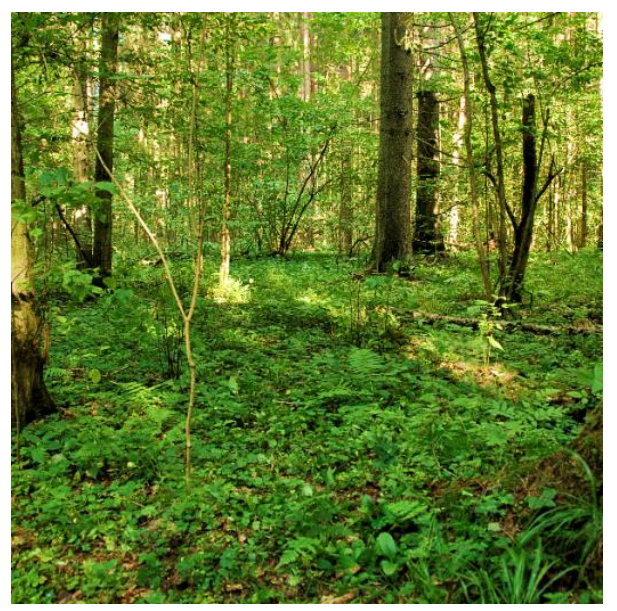

(g)

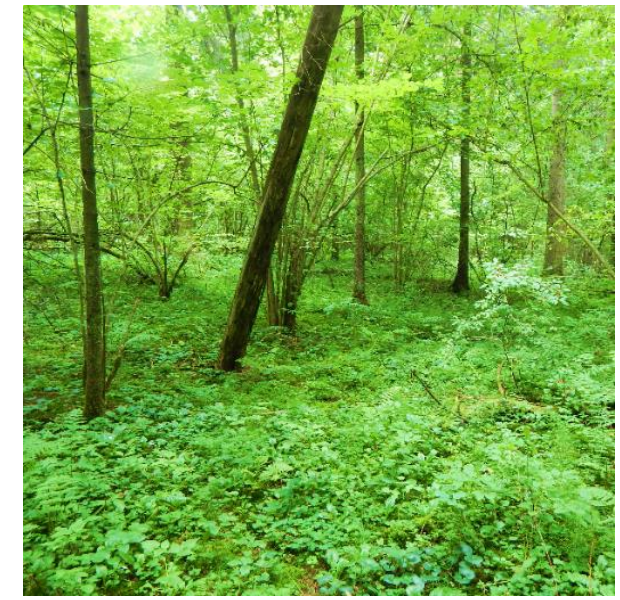

(d)

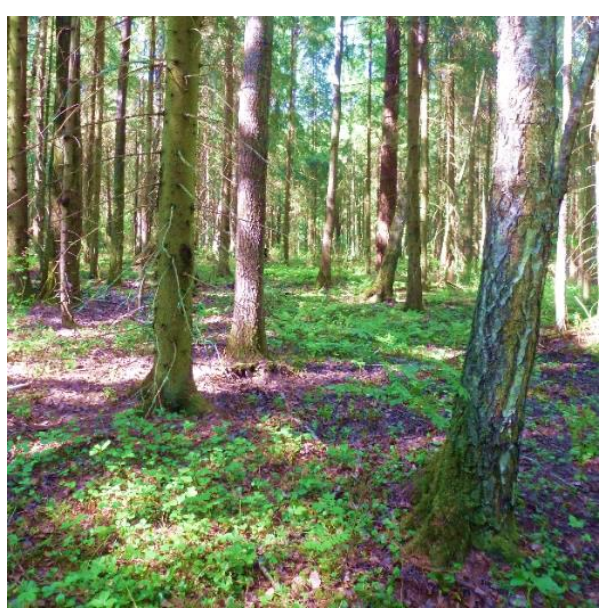

(f)

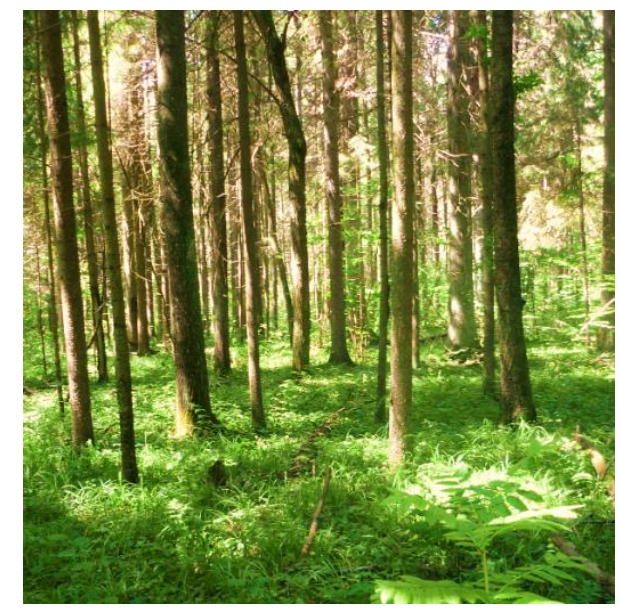

(h)

Figure 5. Photographs of plant communities: (a) spruce with birch and pine DShG (photo by O. Morozova); (b) spruce with birch and pine Sh (photo by O. Morozova); (c) spruce with birch ShBh (photo by O. Morozova); (d) spruce with birch, lime and oak Bh; (e) spruce-aspen/birch with pine DShG (photo by O. Morozova); (f) spruce-aspen/birch Sh (photo by N. Belyaeva); (g) spruce-aspen/birch ShBh (photo by O. Morozova); and (h) spruce-aspen/birch with lime and oak Bh (photo by T. Chernenkova). 


\subsubsection{Tree Layer}

The tree layer composition of spruce and spruce-aspen/birch forests differs in the ratio of coniferous and deciduous trees (Figure 6a). Spruce-aspen/birch forests include communities where spruce and birch are present in equal proportions (with a small mixture of aspen).

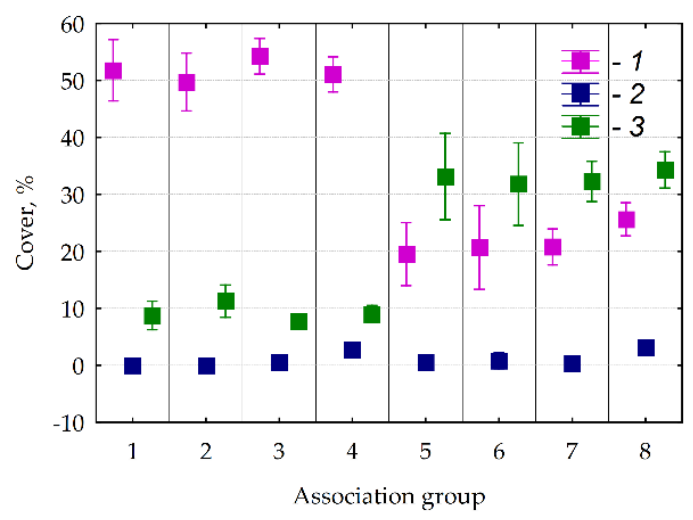

(a)

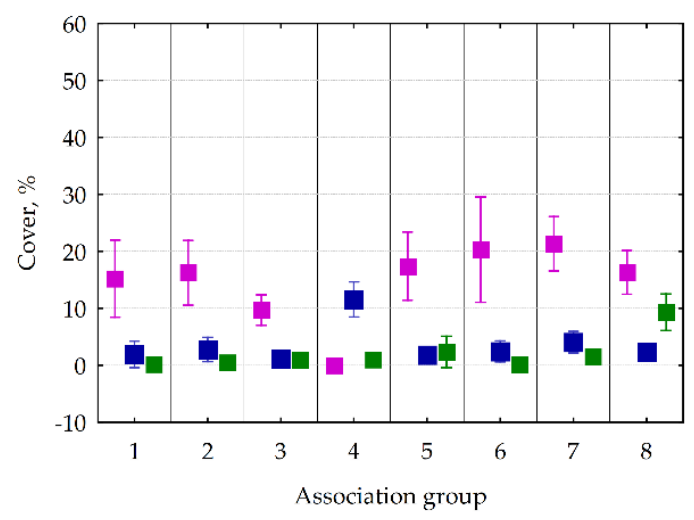

(b)

Figure 6. Cover and composition of tree layer in 8 association groups: (a) A1 and (b) A2; 1 -spruce, 2-broad-leaved species (oak and lime) and 3-aspen/birch. Box-whisker type: mean/std.err.

The spruce stands are defined by an uneven age (on average A1-95 and A2-65 years) and consist, as a rule, of 2 layers with an average cover of $65 \%$ and $32 \%$, respectively (Table A2). In A1, the ratio of spruce and aspen/birch species (mainly birch) is stable at 4:1 (Figure 6a). However, in A2, the situation is different-in the group of Bh spruce forests, the proportion of spruce plummets, while that of birch, on the contrary, soars (Figure 6b). This fact points to the silvicultural origin of the Bh spruce forests without spruce regeneration. In the future, they will be replaced by broad-leaved species. This is confirmed by the nemoral composition of the ground layer.

The proportion of broad-leaved tree species is negligible. There is a trend that, from group 1 to group 4 in the second layer of the stand (A2), the abundance of broad-leaved tree species varies from $3 \%$ to $15 \%$. Thus, in DShG spruce forests, only single trees of Tilia cordata $(5 \%)$ and Quercus robur (3\%) occur in A2, but in Bh spruce forests, lime (15\%) and oak (11\%) occur regularly and lime is actively renewing (B-12\%).

The communities of spruce-aspen/birch formations are younger, A1-75 years old and A2-about 50 years old, which corresponds to the successional status of this group of forests. The total cover of the tree layer is $70 \%$; the cover of $\mathrm{A} 1$ is $60 \%$ and the cover of $\mathrm{A} 2$ is about $40 \%$ (Table A2). The proportions of spruce and small-leaved species are approximately equal; although in the A1 layer, the cover of small-leaved species (mainly birch) is higher than that of spruce, in A2, on the contrary, spruce significantly prevails over birch in terms of abundance. Typically, the broad-leaved species cover in the Bh group of associations (\#4) is higher, especially in A2 and the abundance of spruce and birch is lower compared to other association groups (Figure 6b).

\subsubsection{Vegetation of Understorey Layers}

The composition of the understorey layers in communities is characterized by more significant differences. In the sequence of community groups from \#1 to \#4, the shrub layer cover varies from $20 \%$ to $35 \%$, which is mainly related to the abundance of Corylus avellana (Figure 7 ). The cover of the dwarf shrub-herb layer varies from $60 \%$ to $68 \%$, whereas the moss cover varies from $55 \%$ to $24 \%$ in this sequence. Although in DShG communities in the moss layer typical boreal species prevail (Pleurozium schreberi (25\%) and Hylocomium splendens (15\%), Dicranum polysetum (6\%) and D. scoparium $(4 \%))$, and nemoral species such as Plagiomnium affine (4\%), Rhodobryum roseum (6\%) and Sciuro-hypnum 
curtum (1\%) are rare and their coverage is small, the Bh type has a polydominant composition of nemoral and boreal moss species-Atrichum undulatum (3\%), Cirriphyllum piliferum (2\%), Eurhynchium angustirete (8\%), Plagiochila porelloides (4\%), Plagiomnium undulatum (6\%), P. affine (3\%), Pleurozium schreberi (5\%), Sciuro-hypnum curtum (3\%), S. starkei (2\%), Rhytidiadelphus triquetrus (4\%), Hylocomium splendens $(5 \%)$.

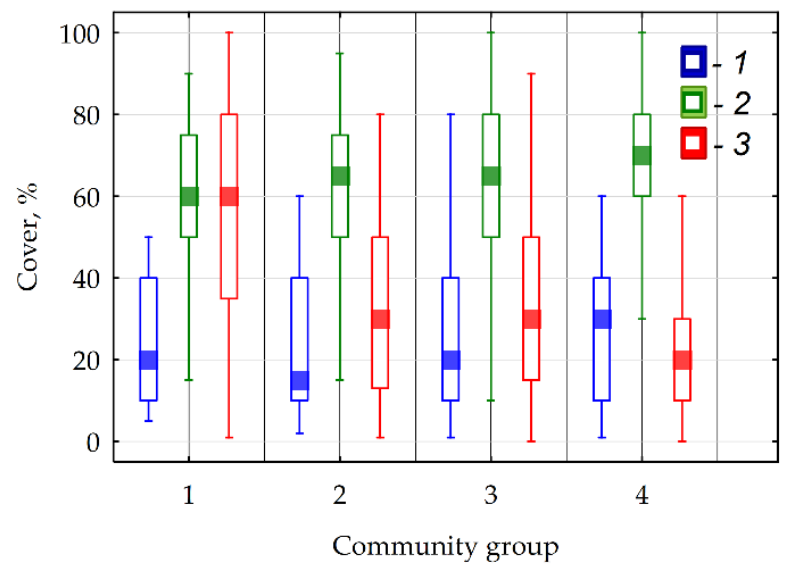

Figure 7. Cover of understorey in spruce and spruce-aspen/birch communities: 1—shrub layer, 2—warf shrub-herb layer and 3-moss layer. Community groups: 1-DShG, 2-Sh; 3-ShBh and 4-Bh. Box-whisker type: median/25 and 75 percentiles/nonoutlier range.

The specified classes are clearly distinct according to the diagnostic criteria of subordinate layer vegetation-indicator species and ecological-coenotic groups of species.

The indicator species of the DShG group of communities (\#1) with high IndVal (IV) values include green mosses (Pleurozium schreberi and Hylocomium splendens), small boreal shrubs such as blueberry and cowberry and typical boreal small herb species. The ground layer of spruce Sh forests (\#2) has only two indicator boreal species: Oxalis acetosella and Mycelis muralis. Spruce ShBh forests (\#3) have Corylus avellana in the shrub layer and the nemoral species Ajuga reptans in the herb layer. The large number of diagnostic nemoral species in spruce forests (\#4) shows that these are mature spruce communities (Table 3).

Table 3. Indicator values (IndVal) for species in community groups of spruce and spruce-aspen/ birch forests.

\begin{tabular}{|c|c|c|c|c|c|c|c|}
\hline \multicolumn{8}{|c|}{ Community Group } \\
\hline \multicolumn{2}{|l|}{ \#1-DShG } & \multicolumn{2}{|l|}{ \#2-Sh } & \multicolumn{2}{|l|}{ \#3-ShBh } & \multicolumn{2}{|l|}{$\# 4-\mathrm{Bh}$} \\
\hline Species & IV & Species & IV & Species & $I V$ & Species & IV \\
\hline Pleurozium schreberi & 69 & Oxalis acetosella & 34 & Corylus avellana (B2) & 28 & Galeobdolon luteum & 45 \\
\hline Vaccinium myrtillus & 60 & Mycelis muralis & 25 & Oxalis acetosella & 27 & Aegopodium podagraria & 43 \\
\hline Hylocomium splendens & 52 & & & Ajuga reptans & 26 & Carex pilosa & 43 \\
\hline Frangula alnus (B2) & 44 & & & & & Ranunculus cassubicus & 41 \\
\hline Vaccinium vitis-idaea & 39 & & & & & Corylus avellana (B2) & 37 \\
\hline Calamagrostis arundinacea & 37 & & & & & Pulmonaria obscura & 32 \\
\hline Orthilia secunda & 35 & & & & & Dryopteris filix-mas & 31 \\
\hline Luzula pilosa & 32 & & & & & Stellaria holostea & 31 \\
\hline Maianthemum bifolium & 30 & & & & & Asarum europaeum & 30 \\
\hline Trientalis europaea & 30 & & & & & & \\
\hline
\end{tabular}

Note. We show here species with IndVal $>25$ and significance value $<0.05$.

While the species composition of the community groups differs significantly, the indicators of species diversity are quite similar (Table A3). The number of species per unit area (species richness) of the herb-dwarf shrub layer varies slightly across community classes, ranging from 29 (boreal species) 
to 26 species (nemoral species). The number of bryophyte species compared in the community groups does not differ significantly. The minimum species diversity (201 species) due to the low number of species in the herb layer was characteristic of the Bh community group (\#4). The cover of the herb-dwarf shrub layer was maximum here (Figure 7) and significantly differed from other community groups $\mathrm{F}(3.605)=5.278, p<0.01$. The maximum species richness (232 species) was observed in the ShBh group (\#3), which naturally reflects the mixed floristic composition of these communities.

The total species richness of the community groups (including vascular plants and bryophytes of all layers of the community) was relatively high (341 species). That richness included: 27 trees, 21 shrubs, 5 small shrubs, 227 herbaceous plants and 61 bryophytes. The maximum number of bryophyte species in the Bh community group (\#4) was 61 (Table A4).

The communities of the four groups considering only the species of subordinate layers are divided based on the species composition in the ordination space (Figure 8). The leading differentiation factors characterized according to the Ellenberg scales are light, soil nutrients, soil reaction and moisture. Changes in soil reaction, nutrients and light are related to the first variation axis, whereas moisture is connected with the second axis. The correlation with soil reaction $\left(r^{2}=0.51\right)$ and nutrients $\left(r^{2}=0.35\right)$ is the most considerable (Table A6).

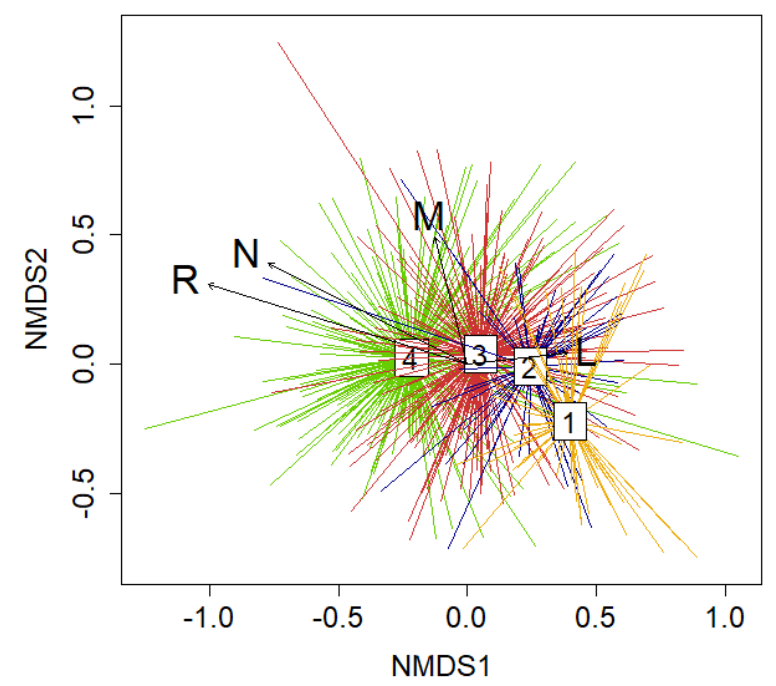

Figure 8. NMDS ordination of community groups of spruce and spruce-aspen/birch formations (understorey species composition). L-light, $\mathrm{M}$-moisture, $\mathrm{N}$-nutrients, $\mathrm{R}$ - soil reaction. Community groups: 1-DShG, 2-Sh; 3-ShBh and 4-Bh.

Analysis of the four forest community groups (DShG, Sh, ShBh and Bh) showed the special features of their variety in terms of species and typological diversity, with the transition from boreal species composition to the nemoral composition. For instance, within the sequence from the DShG group (\#1) to the Bh group (\#2) in the ecological spectrum, the proportion of boreal species decreased by a factor of 3.5 , whereas the proportion of the nemoral species group tripled.

\subsection{Spatial Distribution of Forests}

According to our estimates, the total forest cover of the studied area is $51 \%$, the proportion of spruce forests is $18 \%$ of the total area of the forest territory, the proportion of spruce-aspen/birch forest is $19 \%$, the proportion of pine forest is $14 \%$, the proportion of broad-leaved forest is about $8 \%$ and the proportion of broad-leaved-spruce forest is $1 \%$. The maximum proportion belongs to the secondary forest communities with dominance of birch and aspen-it is more than $30 \%$ [80]. The distribution of formations and association groups is related to natural conditions-primarily to the soil-geomorphological and climatic conditions (Figure 9). 


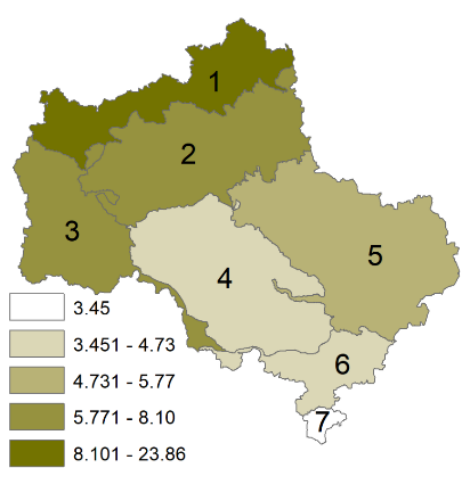

(a)

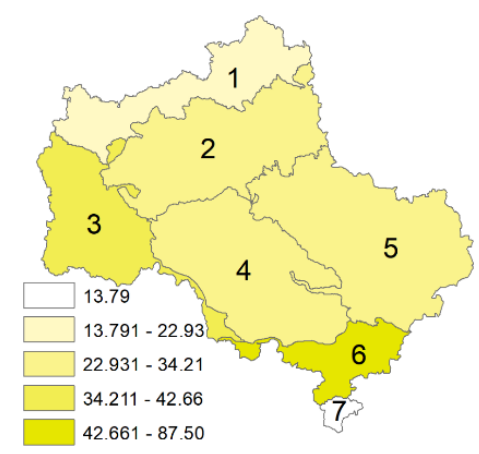

(c)

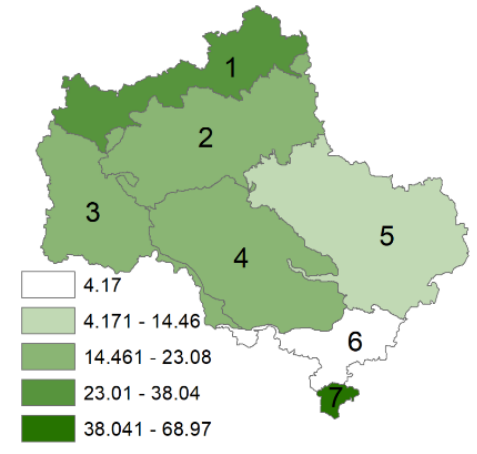

(b)

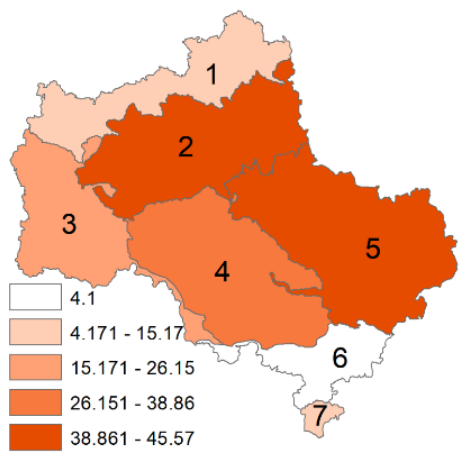

(d)

Figure 9. Proportion (\%) of association groups with breakdown by province: (a) DShG, (b) Sh, (c) ShBh and (d) Bh; province numbers: 1-Verkhnevolzhskaya, 2-Moskovskaya, 3-Smolenskaya, 4-Moskvoretsko-Okskaya, 5-Mescherskaya, 6-Zaokskaya and 7-Srednerusskaya.

The extent of spruce forests is the maximum in the elevated northern and western provinces (\#2 and \#3), which correlates with the thickness of the loamy terminal moraine deposits. The extent of spruce-aspen/birch forests is significant in northern lowland province \#1, which is characterized by lighter and better drained sand and loam-sand fluvioglacial deposits. The extent of spruce-aspen/birch forests in central provinces \#4 and \#5 dominates over the extent of spruce forests due to the low thickness of the loamy moraine deposits. DShG and Sh forests are typical for the northern lowland province \#1, where the loam-sand fluvioglacial deposits as well as wetland habitats prevail. The extent of ShBh forests is greater in the south and southwest, which is connected with the high nutrient content of the underlying sediments (combined with drainage). The distribution of the Bh group is not entirely consistent with the distribution of the ShBh group, which can be explained by the contrast of hydromorphic conditions. In province \#2, the soils have low water permeability because of the moraine loams and in province \#5, it is due to the impermeability of the Jurassic clay bedrock. This distribution of boreal and nemoral type communities in the latitude direction reflects the zonal patterns of vegetation in the study area. A major extent of nemoral spruce communities in provinces \#2 and \#5 is connected with the "warming" effect of the megalopolis (Figure 9a,b). Yet, this assumption requires further research.

\subsection{Spatiotemporal Dynamics of Spruce Plantations: An Example of the South-Western Part of the Moscow Region}

As an example, we considered the occurrence of forest plantations in the forests on the moraine and moraine-fluvioglacial plains of the Smolenskaya province (\#3) with the area of 51,500 hectares. Forests cover $56 \%$ of that area. The forests are mainly represented by natural forests $(76 \%$ of the forested area). Plantations account for $22 \%$ of the forested area and the proportion of felled areas (without 
creating plantations) is $2 \%$ (Figure 10). In other parts of the region, the proportion of plantations is higher and reaches to $32 \%$ [88,89].

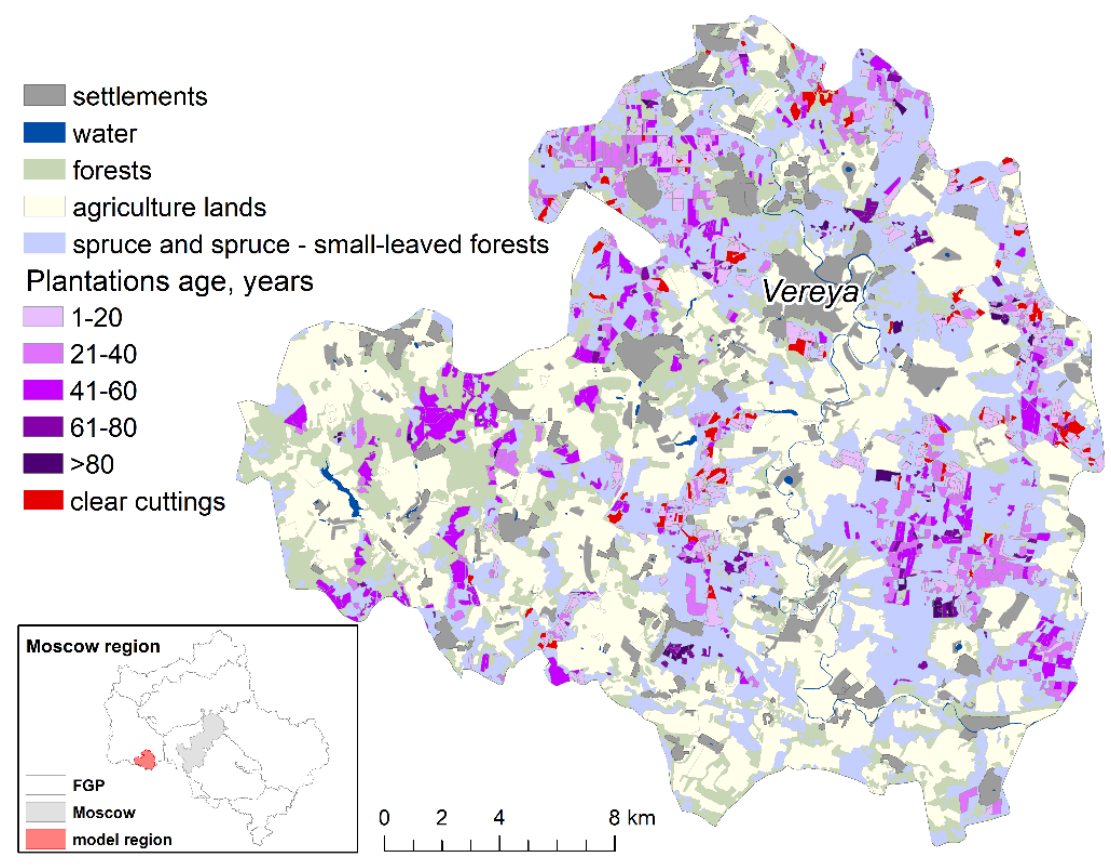

Figure 10. Main patterns of land cover and forests of various origins for the test plot.

Spruce is the most widespread species used in silviculture (80\% of all plantations), whereas pine and heterogeneous plantations account for a mere $6.5 \%$ and $5 \%$, respectively. Besides, there are oak and larch plantations. Forest plantations often occur under the canopy of various species and their combinations: birch, birch and aspen, oak, spruce, spruce and birch, grey alder, aspen and lime. There is one case when forest plantations were created to replace old plantations aged 100.

According to forest inventory data, the oldest plantation in the area under study is dated 1891. Overall, according to the forest inventory data, prior to 1941 (before WWII), 281,500 hectares of forest were planted.

Spruce and spruce-aspen/birch forests account for $57 \%$ in that area, while the proportion of plantations is only $20 \%$ of those forest communities. However, for instance, the proportion of plantations is $27 \%$ among spruce Sh communities and among spruce-aspen/birch ShBh communities, it is $24 \%$. It is worthy of note that even in aspen/birch forests the proportion of plantations is large; for instance, in birch Bh forests, one-third of the forests are silviculture stands and the forest inventory data show this. These are probably the plantations which did not survive without the necessary care and birch dominated them. As spruce and spruce-aspen/birch communities have a large proportion of stands aged 80 and older, the proportion of silviculture stands should be much bigger.

In general, the distribution of plantations in terms of age in this model area is typical of the Moscow Region. Stages II and III (aged 21-40 and 41-60) and stage I (aged below 20) coniferous plantations cover the largest areas $(64 \%$ and $28 \%$, respectively). Stage V and VI plantations (aged over 80 ) occur most rarely- $8 \%$ (Figure 10), which may be related to the fact that silviculture stands are excluded from the category of plantations aged over 80 in official sources (according to the forest inventory data).

\section{Discussion}

The regeneration of spruce communities with aspen and birch within the study area can proceed by either of two scenarios. According to the first scenario, the spruce population is formed during the primary overgrowth of felling or arable land with aspen and birch trees in the first 20-30 years or during 
the late regeneration of spruce that gradually enters the main canopy [90,91]. Spruce-aspen/birch forests, which include mainly spruce (Picea abies) and small-leaved tree species such as birch (Betula pubescens s. 1., B. pendula) and aspen (Populus tremula), are regarded by many researchers [92-95] as a short-term secondary stage of spruce forests formed at logging sites as a result of both spontaneous succession and the development of spruce plantations. Aspen and birch trees preceding or accompanying the development of the spruce population are characterized by a high intensity of the production process [96,97]. Our study highlights another scenario: the mixed composition is formed as a result of active birch regeneration in spruce plantations with poor quality of tending. The frequent absence of tending in the Moscow Region in the last two decades has determined a large share of spruce-aspen/birch forests, the mixed composition which results from active birch regeneration in poorly tended spruce plantations [91]. According to experienced foresters [39] and old official data, the majority of spruce forests are plantations and covers $60-80 \%$ in the region.

The dynamic processes in spruce plantations studied in the example of the study area are generally consistent with the well-known "model of stand dynamics" developed for forests in Western North America [98]. After the disturbance, the community goes through the stages of initialization, canopy closing, biomass accumulation, maturation and vertical and then horizontal differentiation, reaching the stage of maturity. According to our study, the canopy closing changes the course of succession. The understorey of mature spruce plantation communities becomes similar to natural forests which comply to $[99,100]$. Our data showed that mature and elderly spruce plantation forests (over 80 years old) are similar to natural forests in terms of their structural and floristic characteristics, which is confirmed by the data from other studies [14,101,102].

The species diversity of vascular plants and bryophytes in communities of spruce plantations older than 80 years is comparable to that in natural spruce forests. The total species richness of the spruce communities (including species of vascular plants and bryophytes at all levels of communities) was relatively high-341 species. Out of these species, 27 were trees, 21 -shrubs, 5-dwarf shrubs, 227-herbaceous plants and 61-bryophytes. The maximum number of bryophyte species in the Bh community group was 61. This data complies with well-known studies [14,103-105].

The different data on species diversity in plantation forests are determined by various factors during their exploitation. The management regime should also be taken into consideration. For the forest plantations of Japan (where their proportion is $40 \%$ of area), it is shown that for uneven-aged stands, thinning and line cutting in plantations could improve the species richness or diversity of plant species [106,107], while after repeated rotation, the species richness decline [108]. Additionally, there is a recreational factor that influences the species richness. For example, the species richness in suburban forests of the Czech Republic is high and mostly depends on the human influenced landscape structure (distance to settlements, roads, etc.) [109]. For suburban Fagus sylvatica stands, it is demonstrated that the species richness, also the cover and height, of the herb and moss layer is lower in regularly visited forests [110]. Innovative forest management practices compared with traditional thinning result in higher stand productivity along with better structural and functional variables [111]. The data presented in current study allow us to challenge the hypothesis of low species diversity in silviculture stands [17,112]. However, the abovementioned studies conducted in the UK and Canada are justified for fast-growing plantations of introduced species that are cut down already at the age of 40 . The authors note that a significant part of the floristic diversity, including vascular plants, in natural forests is due to the parcel and gap structure of forests. The importance of gap dynamics is also confirmed for temperate secondary forest ecosystems in Northeast China [113]. The age of young plantations (20-40 years old) is not sufficient for the internal structure of communities to develop. According to Ulanova [101], in the first 25 years of spruce plantation development after logging, the species diversity decreases, while there is a significantly high negative relationship $(r=-0.90)$ between the number of species at the site and the time after logging. Our data did not show such a significant correlation in the study of plantations with the age up to 20 years $(r=-0.48)$. We assume that the relatively high heterogeneity of the habitat and the appearance of weed and meadow-edge 
species [101] is due to the lack of proper care of plantations. In addition, the impact of forestry, namely, weeding and thinning of plantations, reduces the canopy closure of communities, giving the light-demanding species an opportunity to remain in the communities.

For the spruce and spruce-aspen/birch plantation forests, the well-known regularities of boreal and nemoral forest distribution with respect to latitude are confirmed, which reflects the zonal features of vegetation in the study region and is consistent with the studies of the spatial distribution of other types: broad-leaved-coniferous [114] and pine forests [115]. The majority of the communities dominated by spruce on the uplands in the center of the Russian plain in the zone of coniferous and broad-leaved forests should be regarded as secondary communities formed as a result of centuries-long forest management (logging, fires and forest planting), often alternating with agricultural activities. According to our estimates, the proportion of spruce and spruce-aspen/birch communities in the forest-covered area of the territory under study reaches about $37 \%$. This indicator varies from $30 \%$ to $0.2 \%$ from northwest to southeast within the boundaries of the physiographic provinces. This regularity follows the change of zones- the transition from the coniferous and broad-leaved forest zone to the broad-leaved forest one.

The community composition was determined to form mainly based on growth conditions. Thus, in the study area, the DShG spruce forests are found on slopes of moraine rocks with middle sod-podzolic-middle loamy and sandy soils, with a groundwater level of 2-4 m [45]. Sh spruce forests are usually widespread on gentle slopes of low hills on fluvioglacial plains. According to the same authors, spruce forests with blueberry are more widespread in habitats with better drainage, in upper parts of moraine rocks with middle sod-podzolic and light loamy soils and with groundwater levels exceeding $4 \mathrm{~m}$. ShBh spruce forests occur on arching and leveling parts of upland plateaus with middle podzolic light loamy and well-drained soils and are located close to uplands and moraine hills, mainly on slopes.

Spruce predominates on the elevated loamy final moraine deposits, whereas spruce-aspen/birch forests prevail on loam-sandy glaciofluvial deposits. In particular, DShG and Sh communities are the most characteristic of the Verkhnevolzhskaya (\#1) province as, on the one hand, loam-sandy glaciofluvial deposits dominate there and on the other hand, the extent of bogging is noticeable.

Dispersion analysis of the distribution of various spruce forest and terrain types showed that the spruce forest types, which we identified, are determined by terrain and are statistically significant [116]. For instance, DShG spruce forests occur in the lowest and flattest areas with slight slopes. Sh spruce forests are spread in the lowest and concave terrain shapes. ShBh spruce forests are found on elevated, slightly concave surfaces with gentle slopes, whereas nemoral Bh spruce forests are located on the most elevated and arching terrain types with steep slopes.

Evidence suggests that mixed plantations (pine and spruce) are more stable and $40 \%$ more productive compared with monodominant ones [117,118]. As severe climate conditions are becoming more and more frequent in the studied region, according to the stress gradient hypothesis (SGH) [119], mixed plantations can be a good solution to maintain the ecological potential of forest cover. In particular, the reestablishment of pine plantations is appropriate, especially on river terraces on sandy loam soils, while mixed plantations of pine and spruce are promising on upland loam soils. It is worthy of note that the conditions in coniferous plantations may be favorable for the protected lichen species [17]. Our data and other studies [120] confirm the conclusion that it is necessary to involve ecosystem-oriented forest management afforestation actions when developing an optimum model of forest management.

\section{Conclusions}

We studied the spruce (Picea abies (L.) H. Karst.) forests within the Moscow Region. The Moscow region is feasible case study area for spruce forests on the south boundary of their range in the center of the Russian plain. Most of spruce forests are silviculture forests. The study area is also currently under weak forest management (frequent absence of tending in plantation forests). Our study is based on 
multidisciplinary research project and concerns the biodiversity and pattern of spruce forests, as well as age dynamics of spruce plantation forests.

The succession of spruce communities under poor tending begins with active birch regeneration and forming of mixed composition. From the forest management point of view, this is undesirable, as it reduces the forestry value of the main coniferous species; at the worst, spruce plantations collapse. However, the early successional species (birch and aspen) improve the edaphic properties of the soil, enriching it with biogenic elements and accumulating litter biomass, which is important to conserve biodiversity and normalize environmental processes.

During the age dynamics under the canopy of plantations, especially the pine ones, active restoration of tree species characteristic of natural forests was observed. Spruce plantations, in turn, maintain the floristic composition of the herb-dwarf shrub layer, which is the closest to the original and its recovery is faster than in pine plantations. The processes of vegetation dynamics in spruce plantation forests are faster than natural secondary succession as the stage when aspen and birch prevail is absent. Mature spruce and spruce-aspen/birch communities (the previous successional variant) are similar in structure and composition to the conditionally natural types of boreal and nemoral spruce forests. Importantly, the successional dynamics of forest plantations at the initial stages is mainly determined by the tending measures.

Despite significant anthropogenic impact and a high proportion of silviculture stands, these communities match the composition of zonal spruce communities of broad-leaved-coniferous forests in terms of floristic richness and typological diversity.

Analysis of the physiographical conditions confirmed the relationship between the distribution of spruce formations and the climatic gradient, as well as with the changes in geomorphological conditions associated with the position of the area relative to the limit of the Moscow glaciation. The relationship between nemoral (ShBh) forests and the drainage gradient of the underlying rocks may not be the sole key factor. In particular, the larger proportion of nemoral spruce communities in the area surrounding the Moscow urban agglomeration may be connected with the "warming" effect of the megalopolis, leading to the nemoralization of community composition. Yet, this hypothesis requires further research.

Based on the above analysis, we propose general recommendations for the management of sylvicultural spruce forests. Spruce plantation forests, especially in areas with a strong anthropogenic impact, with free seed access, have a potential for restoring the floristic diversity of natural forests, performing recreational and ecological functions. The widespread phenomenon of intensive decay of mature spruce forests in recent years, as well as the vulnerability of spruce plantation forests to dendrophagous insects, justifies the need to evaluate their combination with pine plantation forests. Spruce forests, as well as those combined with pine plantation forests, are promising for cultivation in the moraine plain on fresh, well-drained soils in the Moscow Region. Over-matured plantations can provide valuable habitats for the re-establishment of native biodiversity when seed sources are available. This enables silviculture stands to be used as a better alternative to natural overgrowth of disturbed habitats. In this case, plantations can also serve as buffers or ecological corridors between fragments of disturbed territories.

Author Contributions: T.C. designed the study, T.C., N.B., E.S., O.P., O.M. and M.A., conducted the fieldwork, O.P. and T.C. did research and the data analysis of silviculture stands, T.C., I.K. and N.B. did the data analysis of natural forests and I.K. did most of the digital modeling. All authors have read and agreed to the published version of the manuscript.

Funding: This study was conducted in the framework of the Institute of Geography RAS (project no. 0148-2019-0007) in terms of studying the composition of forest communities. The Russian Science Foundation (project no. 18-17-00129) supports studies of spatial analysis of forest biodiversity.

Acknowledgments: The authors thank E.A. Ignatov for identifying bryophytes and E.V. Tikhonova for participating in field surveys.

Conflicts of Interest: The authors declare no conflicts of interest. 


\section{Appendix A}

Table A1. General properties of physiographic provinces of Moscow Region; values in the table are means \pm SD

\begin{tabular}{|c|c|c|c|c|c|c|c|}
\hline & \multicolumn{7}{|c|}{ Provinces } \\
\hline & Verkhnevolzhskaya & Moskovskaya & Smolenskaya & Moskvoretsko-Okskaya & Mescherskaya & Zaokskaya & Srednerusskaya \\
\hline & $\# 1$ & $\# 2$ & $\# 3$ & $\# 4$ & $\# 5$ & $\# 6$ & $\# 7$ \\
\hline Number of glaciations & 4 & 3 & 3 & $2-3$ & $2-3$ & 2 & 2 \\
\hline \multicolumn{8}{|c|}{ Climate } \\
\hline $\mathrm{T}_{\mathrm{avg} \text { jan }}\left({ }^{\circ}\right)$ & $-9.65 \pm 0.69$ & $-9.16 \pm 0.6$ & $-8.94 \pm 0.57$ & $-8.27 \pm 0.29$ & $-8.78 \pm 0.52$ & $-8.85 \pm 0.22$ & $-8.63 \pm 0.09$ \\
\hline $\mathrm{T}_{\text {avg jjuly }}\left({ }^{\circ}\right)$ & $17.49 \pm 0.21$ & $17.47 \pm 0.37$ & $17.25 \pm 0.28$ & $18.10 \pm 0.42$ & $18.79 \pm 0.32$ & $18.52 \pm 0.27$ & $18.50 \pm 0.1$ \\
\hline $\begin{array}{l}\text { Annual precipitation } \\
(\mathrm{mm})\end{array}$ & $637 \pm 9.96$ & $652 \pm 9.62$ & $636 \pm 9.81$ & $621 \pm 21.5$ & $614 \pm 27.47$ & $574 \pm 9.46$ & $558 \pm 3.88$ \\
\hline $\begin{array}{c}\text { Precipitation of } \\
\text { warmest month }(\mathrm{mm})\end{array}$ & $86.2 \pm 2.03$ & $87.6 \pm 1.64$ & $84.6 \pm 0.78$ & $84.6 \pm 1.03$ & $86.9 \pm 2.53$ & $82.3 \pm 1.31$ & $79.0 \pm 0.65$ \\
\hline \multicolumn{8}{|c|}{ Relief } \\
\hline Elevation $(\mathrm{m})$ & $146.7 \pm 18.6$ & $206.8 \pm 29.47$ & $213.1 \pm 30.92$ & $174.4 \pm 25.63$ & $133.5 \pm 16.80$ & $168.6 \pm 29.86$ & $176.4 \pm 23.46$ \\
\hline Slope $\left(^{\circ}\right)$ & $3.54 \pm 2.74$ & $5.18 \pm 3.81$ & $4.85 \pm 3.73$ & $4.49 \pm 3.5$ & $3.74 \pm 2.88$ & $4.58 \pm 3.59$ & $3.75 \pm 2.89$ \\
\hline \multicolumn{8}{|c|}{ Surface deposits, soils and vegetation } \\
\hline Deposits & $\begin{array}{c}\text { Outwash, } \\
\text { moraine-fluvioglacial, } \\
\text { shale loam and sands, } \\
\text { underlain by } \\
\text { limestones or clays }\end{array}$ & $\begin{array}{l}\text { Moraine, } \\
\text { moraine-fluvioglacial } \\
\text { loam and sand }\end{array}$ & $\begin{array}{l}\text { Moraine loam, } \\
\text { fluvioglacial and } \\
\text { limno-fluvioglacial } \\
\text { loams and sands }\end{array}$ & $\begin{array}{l}\text { Moraine and } \\
\text { moraine-fluvioglacial } \\
\text { loams and sands }\end{array}$ & $\begin{array}{c}\text { Fluvioglacial, } \\
\text { ancient alluvial } \\
\text { sands and loams }\end{array}$ & $\begin{array}{c}\text { Shale loess-type loams on } \\
\text { moraine and fluvioglacial } \\
\text { sands }\end{array}$ & $\begin{array}{l}\text { Shale and moraine, } \\
\text { fluvioglacial loams } \\
\text { on rock outcrops }\end{array}$ \\
\hline Soil & $\begin{array}{l}\text { Sod-podzolic, } \\
\text { gleyic soils }\end{array}$ & $\begin{array}{l}\text { Sod-podzolic, } \\
\text { gleyic, wetland soils }\end{array}$ & Sod-podzolic soils & $\begin{array}{l}\text { Sod-podzolic, } \\
\text { light grey forest soils }\end{array}$ & $\begin{array}{l}\text { Sod-podzolic, } \\
\text { podzolic gleyic, } \\
\text { wetland soils }\end{array}$ & $\begin{array}{l}\text { Grey forest, light grey } \\
\text { forest soils }\end{array}$ & Grey forest soils \\
\hline Forests & $\begin{array}{c}\text { Birch-pine, } \\
\text { spruce-aspen/birch }\end{array}$ & $\begin{array}{l}\text { Broad-leaved—spruce, } \\
\text { spruce—aspen/birch }\end{array}$ & $\begin{array}{l}\text { Broad-leaved-spruce, } \\
\text { spruce—aspen/birch }\end{array}$ & Aspen/birch & $\begin{array}{l}\text { Spruce-oak-pine, } \\
\text { birch-pine }\end{array}$ & $\begin{array}{c}\text { Aspen/birch, } \\
\text { Aspen/birch—broad-leaved }\end{array}$ & Oak \\
\hline
\end{tabular}


Table A2. Results of linear discriminant analysis (LDA) classification. Cells: percent of initial groups recognized correctly or as other group.

\begin{tabular}{|c|c|c|c|c|c|c|c|c|c|c|}
\hline & & \multicolumn{8}{|c|}{ Predicted Association Group } & \multirow{2}{*}{$\begin{array}{c}\text { Total Number } \\
\text { of Relevés }\end{array}$} \\
\hline & & \multicolumn{4}{|c|}{ Spruce Forests } & \multicolumn{4}{|c|}{ Spruce-Aspen/Birch Forests } & \\
\hline & & DShG & Sh & ShBh & Bh & DShG & Sh & ShBh & $\mathrm{Bh}$ & \\
\hline & & 1 & 2 & 3 & 4 & 5 & 6 & 7 & 8 & \\
\hline \multirow{8}{*}{$\begin{array}{l}\text { Initial } \\
\text { association } \\
\text { group }\end{array}$} & 1 & 16.2 & 2.7 & 24.3 & 0.0 & 0.0 & 2.7 & 5.4 & 0.0 & 37 \\
\hline & 2 & 0.0 & 30.8 & 12.8 & 2.6 & 0.0 & 2.6 & 7.7 & 0.0 & 39 \\
\hline & 3 & 2.3 & 8.3 & 33.1 & 12.8 & 1.5 & 1.5 & 1.5 & 1.5 & 133 \\
\hline & 4 & 1.4 & 5.7 & 16.3 & 27.0 & 0.0 & 0.7 & 7.1 & 2.1 & 141 \\
\hline & 5 & 7.1 & 0.0 & 7.1 & 0.0 & 50.0 & 0.0 & 14.3 & 0.0 & 14 \\
\hline & 6 & 0.0 & 7.1 & 7.1 & 7.1 & 7.1 & 50.0 & 7.1 & 0.0 & 14 \\
\hline & 7 & 0.0 & 0.0 & 0.0 & 0.0 & 0.0 & 5.3 & 89.5 & 0.0 & 19 \\
\hline & 8 & 0.0 & 13.0 & 13.0 & 11.6 & 5.8 & 1.4 & 2.9 & 2.9 & 69 \\
\hline
\end{tabular}


Table A3. Dendrometric characteristics of spruce and spruce-aspen/birch communities.

\begin{tabular}{|c|c|c|c|c|c|c|c|c|}
\hline \multirow{2}{*}{ Characteristic } & \multicolumn{4}{|c|}{ Spruce Forests } & \multicolumn{4}{|c|}{ Spruce-Aspen/Birch Forests } \\
\hline & DShG & Sh & ShBh & Bh & DShG & Sh & ShBh & Bh \\
\hline Group \# & 1 & 2 & 3 & 4 & 5 & 6 & 7 & 8 \\
\hline Number of relevés & 37 & 40 & 147 & 148 & 32 & 22 & 81 & 102 \\
\hline Average cover A1 (\%) & $64.1+17.4$ & $59.6 \pm 15.7$ & $64.6 \pm 19.1$ & $85.5 \pm 30.7$ & $56.9 \pm 16.8$ & $51.8 \pm 18.0$ & $56.8 \pm 17.4$ & $64.0 \pm 17.5$ \\
\hline Average cover A2 (\%) & $27.5 \pm 18.5$ & $31.6 \pm 17.7$ & $27.5 \pm 20.3$ & $39.5 \pm 21$ & $33.8 \pm 17.4$ & $27.8 \pm 20.3$ & $37.2 \pm 17.0$ & $43.9 \pm 17.3$ \\
\hline Age A1, years & $84.4 \pm 18.0$ & $77.52 \pm 29.2$ & $94.4 \pm 27.8$ & $85.53 \pm 30.7$ & $77.4 \pm 17.1$ & $52.0 \pm 20.4$ & $67.7 \pm 23.4$ & $70.3 \pm 24.5$ \\
\hline Age A2, years & $58.7 \pm 12.1$ & $60.73 \pm 21.6$ & $66.6 \pm 23.0$ & - & $51.1 \pm 15.2$ & $53.7 \pm 16.3$ & $43.9 \pm 13.4$ & $53.0 \pm 19.5$ \\
\hline Height A1 (m) & $28.6 \pm 3.1$ & $28.7 \pm 4.0$ & $29.1 \pm 3.4$ & $29.4 \pm 3.5$ & $27.7 \pm 2.0$ & $27.9 \pm 3.7$ & $27.7 \pm 3.2$ & $27.0 \pm 4.2$ \\
\hline Height A2 (m) & $18.7 \pm 3.9$ & $19.5 \pm 4.4$ & $18.6 \pm 4.2$ & - & $17.5 \pm 3.1$ & $18.8 \pm 1.8$ & $18.0 \pm 3.0$ & $18.7 \pm 3.6$ \\
\hline Canopy height B1 (m) & $23.3 \pm 15.6$ & $22.0 \pm 17.1$ & $25.4 \pm 18.9$ & $30.0 \pm 20.0$ & $21.7 \pm 16.0$ & $23.1 \pm 16.8$ & $24.7 \pm 15.9$ & $26.4 \pm 15.5$ \\
\hline Undergrowth height B1 (m) & $5.9 \pm 3.2$ & $5.4 \pm 3.3$ & $5.9 \pm 2.9$ & $7.4 \pm 3.2$ & $6.6 \pm 2.6$ & $7.3 \pm 2.6$ & $5.8 \pm 4.0$ & $6.9 \pm 2.9$ \\
\hline Shrub layer cover B2 (\%) & $21.9 \pm 16.5$ & $18.3 \pm 12.0$ & $31.4 \pm 19.3$ & $40.0 \pm 20.0$ & $20.0 \pm 13.3$ & $18.3 \pm 11.0$ & $21.9 \pm 15.2$ & $29.7 \pm 16.8$ \\
\hline Undergrowth height B2 (m) & $2.5 \pm 2.4$ & $2.9 \pm 1.3$ & $3.7 \pm 1.6$ & $3.9 \pm 1.5$ & $2.4 \pm 0.8$ & $2.9 \pm 1.2$ & $3.5 \pm 1.6$ & $4.1 \pm 1.6$ \\
\hline Average cover A (\%) & $68.4 \pm 19.3$ & $67.9 \pm 14.7$ & $69.8 \pm 14.4$ & $71.6 \pm 18.1$ & $61.9 \pm 19.0$ & $58.0 \pm 22.1$ & $66.8 \pm 18.6$ & $74.5 \pm 15.4$ \\
\hline Average shrub layer cover B (\%) & $29.3 \pm 18.6$ & $27.9 \pm 19.1$ & $38.5 \pm 22.2$ & $42.1 \pm 20.5$ & $30.2 \pm 12.8$ & $30.4 \pm 22.3$ & $31.7 \pm 18.7$ & $37.3 \pm 19.7$ \\
\hline
\end{tabular}


Table A4. Species diversity of ground layer vegetation of spruce and spruce-aspen/birch forests.

\begin{tabular}{cccccc}
\hline \multirow{2}{*}{ Characteristic } & \multicolumn{5}{c}{ Community Group } \\
\cline { 2 - 5 } & & \#1-DShG & \#2-Sh & \#3-ShBh * & \#4-Bh * \\
\hline \multirow{2}{*}{ Number of relevés } & 69 & 62 & 228 & 250 \\
\cline { 2 - 6 } & & 224 & 225 & 232 & 201 \\
\cline { 2 - 6 } Species richness, where & Vascular plants & 182 & 182 & 186 & 159 \\
\cline { 2 - 6 } & Mosses & 42 & 43 & 46 & 61 \\
\hline \multirow{2}{*}{$\begin{array}{c}\text { Species richness in relevés, } \\
20 \mathrm{~m} \times 20 \mathrm{~m} \text {, where }\end{array}$} & Herb layer & $26.6 \pm 1.1$ & $28.8 \pm 1.0$ & $28.3 \pm 0.5$ & $26.3 \pm 0.4$ \\
\cline { 2 - 6 } & Moss layer & $5.4 \pm 0.3$ & $5.9 \pm 0.5$ & $6.1 \pm 0.2$ & $5.3 \pm 0.2$ \\
\hline
\end{tabular}

Note. mean \pm standard error of mean. *-to correctly compare the species richness of coenofloras in different community types and to make the sample size equal, the number of relevés for groups 3 and 4 was reduced by random selection (up to 70 relevés).

Table A5. Results of a pairwise comparison of the total species composition of the eight association groups according to Duncan criterion.

\begin{tabular}{|c|c|c|c|c|c|c|c|}
\hline & 2 & 3 & 4 & 5 & 6 & 7 & 8 \\
\hline 1 & 0.223541 & $0.000005^{1}$ & 0.000004 & 0.153435 & 0.019505 & 0.216111 & 0.000003 \\
\hline 2 & & $\overline{0.000194}$ & 0.000003 & 0.011019 & 0.000433 & 0.952495 & 0.000157 \\
\hline 3 & & & 0.003306 & 0.000004 & 0.000004 & 0.000199 & 0.967133 \\
\hline 4 & & & & 0.000004 & 0.000005 & 0.000004 & 0.004074 \\
\hline 5 & & & & & $\overline{0.309557}$ & 0.010588 & 0.000004 \\
\hline 6 & & & & & & 0.000449 & 0.000004 \\
\hline 7 & & & & & & & $\overline{0.000180}$ \\
\hline
\end{tabular}

${ }^{1}$ Bold underline--significant differences.

Table A6. Vectors of environmental factors in the ordination space and their correlation with variation axes.

\begin{tabular}{ccccc}
\hline Ecological Factor & NMDS1 & NMDS2 & $\boldsymbol{r}^{\mathbf{2}}$ & $\boldsymbol{p}$-Value \\
\hline L (light) & 0.99338 & 0.11487 & 0.0712 & $<0.001$ \\
M (moisture) & -0.24866 & 0.96859 & 0.1198 & $<0.001$ \\
N (nutrients) & -0.89179 & 0.45245 & 0.3494 & $<0.001$ \\
R (soil reaction) & -0.95629 & 0.29243 & 0.514 & $<0.001$ \\
\hline
\end{tabular}

\section{References}

1. Consensus Document on the Biology of Picea Abies (l.) Karst (Norway Spruce); Series on Harmonization of Regulatory Oversight in Biotechnology no. 12; OECD Publishing: Paris, France, 1999; p. 42. Available online: https://www.oecd.org/env/ehs/biotrack/46815648.pdf (accessed on 18 July 2020).

2. Safety Assessment of Transgenic Organisms; Volume 2 of OECD Consensus Documents; OECD Publishing: Paris, France, 2006; pp. 1-444. ISBN 92-64-02258-9. Available online: https://www.oecd-ilibrary.org/science-andtechnology/safety-assessment-of-transgenic-organisms_9789264095403-en (accessed on 18 July 2020).

3. Prskawetz, M.; Schadauer, K. Conditions for forest restoration in Austria. Analysis based on forest inventory data. In Proceedings of the International Conference Forest Ecosystem Restoration, Vienna, Austria, 10-12 April 2000; pp. 223-228.

4. Spiecker, H. Silvicultural management in maintaining biodiversity and resistance of forests in Europe-Temperate zone. J. Environ. Manag. 2003, 67, 55-65. [CrossRef]

5. Ellenberg, H. Vegetation Ecology of Central Europe; Cambridge University Press: Cambridge, UK, 1988; pp. 1-731. ISBN 978-0-521-11521-4. 
6. Heinrichs, S.; Ammer, C.; Mund, M.; Boch, S.; Budde, S.; Fischer, M.; Müller, J.; Schöning, I.; Schulze, E.-D.; Schmidt, W.; et al. Landscape-Scale Mixtures of Tree Species Are More Effective than Stand-Scale Mixtures for Biodiversity of Vascular Plants, Bryophytes and Lichens. Forests 2019, 10, 73. [CrossRef]

7. Mitscherlich, G. Wald, Wachstum und Umwelt I: Form und Wachstum von Baum und Bestand; J.D. Sauerländer Verlag: Frankfurt am Main, Germany, 1978; pp. 1-144.

8. Schmidt-Vogt, H. Die Fichte. Band II/3. Waldbau-Ökosysteme-Urwald-Wirtschaftswald-Ernährung-DüngungAusblick; Verlag Paul Parey: Hamburg, Germany; Berlin, Germany, 1991; pp. 1-804.

9. Rodin, A.R. Reforestation considering the types of deforestation in the mixed forest zone of the Russian Plain. Lesn. Vestn. 2001, 2, 30-32. (In Russian)

10. Pisarenko, A.I.; Red'ko, G.I.; Merzlenko, M.D. Iskusstvennye Lesa (Planting Forests); VNIIClesresurs: Moscow, Russia, 1992; pp. 1-548. ISBN 5-88240-006-6. (In Russian)

11. Czerepko, J. Development of vegetation in managed Scots pine (Pinus sylvestris L.) stands in an oak-lime-hornbeam forest habitat. For. Ecol. Manag. 2004, 202, 119-130. [CrossRef]

12. Humphrey, J.W. Benefits to biodiversity from developing old-growth conditions in British upland spruce plantations: A review and recommendations. Forestry 2005, 78, 33-53. [CrossRef]

13. Brockerhoff, E.G.; Jactel, H.; Parrotta, J.A.; Quine, C.P.; Sayer, J. Plantation forests and biodiversity: Oxymoron or opportunity? Biodivers. Conserv. 2008, 17, 925-951. [CrossRef]

14. Nosova, L.M.; Ogureeva, T.N.; Tikhonova, E.V.; Leonova, N.B. Dynamics of Biological Diversity of Coniferous Plantations in the Central Russian Plain. Russ. J. For. Sci. 2009, 6, 18-31. (In Russian)

15. Aubin, I.; Messier, C.; Bouchard, A. Can plantations develop understory biological and physical attributes of naturally regenerated forests? Biol. Conserv. 2008, 141, 2461-2476. [CrossRef]

16. Eycott, A.E.; Watkinson, A.R.; Dolman, P.M. Ecological patterns of plant diversity in a plantation forest managed by clearfelling. J. Appl. Ecol. 2006, 43, 1160-1171. [CrossRef]

17. Humphrey, J.W.; Ferris, R.; Quine, C. Biodiversity in Britain's Planted Forests; Forestry Commission: Edinburg, UK, 2003; pp. 51-62.

18. Onaindia, M.; Mitxelena, A. Potential use of pine plantations to restore native forests in a highly fragmented river basin. Ann. For. Sci. 2009, 66, 7. [CrossRef]

19. Rudel, T.K.; Coomes, O.T.; Moran, E.; Achard, F.; Angelsen, A.; Xu, J.; Lambin, E. Forest transitions: Towards a global understanding of land use change. Glob. Environ. Chang. 2005, 15, 23-31. [CrossRef]

20. Carnus, J.M.; Parrotta, J.; Brockerhoff, E.; Arbez, M.; Jactel, H.; Kremer, A.; Lamb, D.; O’Hara, K.; Walters, B. Planted forests and biodiversity. J. For. 2006, 104, 65-77. [CrossRef]

21. Lähde, E.; Laiho, O.; Norokorpi, Y. Diversity-oriented silviculture in the Boreal Zone of Europe. For. Ecol. Manag. 1999, 118, 223-243. [CrossRef]

22. Hartley, M.J. Rationale and methods for conserving biodiversity in plantation forests. For. Ecol. Manag. 2002, 155, 81-95. [CrossRef]

23. Bremer, L.L.; Farley, K.A. Does plantation forestry restore biodiversity or create green deserts? A synthesis of the effects of land-use transitions on plant species richness. Biodivers. Conserv. 2010, 19, 3893-3915. [CrossRef]

24. Felton, A.; Lindbladh, M.; Brunet, J.; Fritz, Ö. Replacing coniferous monocultures with mixed-species production stands: An assessment of the potential benefits for forest biodiversity in northern Europe. For. Ecol. Manag. 2010, 260, 939-947. [CrossRef]

25. Brockerhoff, E.G.; Ecroyd, C.E.; Leckie, A.C.; Kimberley, M.O. Diversity and succession of adventive and indigenous vascular understorey plants in Pinus radiata plantation forests in New Zealand. For. Ecol. Manag. 2003, 185, 307-326. [CrossRef]

26. Boch, S.; Prati, D.; Müller, J.; Socher, S.; Baumbach, H.; Buscot, F.; Gockel, S.; Hemp, A.; Hessenmöller, D.; Kalko, E.K.V.; et al. High plant species richness indicates management-related disturbances rather than the conservation status of forests. Basic Appl. Ecol. 2013, 14, 496-505. [CrossRef]

27. Paillet, Y.; Bergès, L.; Hjältén, J.; Odor, P.; Avon, C.; Bernhardt-Römermann, M.; Bijlsma, R.J.; De Bruyn, L.; Fuhr, M.; Grandin, U.; et al. Biodiversity Differences between Managed and Unmanaged Forests: Meta-Analysis of Species Richness in Europe. Conserv. Biol. 2010, 24, 101-112. [CrossRef]

28. Stephens, S.S.; Wagner, M.R. Forest Plantations and Biodiversity: A Fresh Perspective. J. For. 2007, 105, 307-313. [CrossRef] 
29. Fang, Z.; Bao, W.; Yan, X.; Liu, X. Understory Structure and Vascular Plant Diversity in Naturally Regenerated Deciduous Forests and Spruce Plantations on Similar Clear-Cuts: Implications for Forest Regeneration Strategy Selection. Forests 2014, 5, 715-743. [CrossRef]

30. Martín-García, J.; Jactel, H.; Oria-de-Rueda, J.; Diez, J. The Effects of Poplar Plantations on Vascular Plant Diversity in Riparian Landscapes. Forests 2016, 7, 50. [CrossRef]

31. Lesnoj Plan Moskovskoj Oblasti Na 2019-2028 Gody (Forest Plan of Moscow Region for 2019-2028); Pravitel'stvo Moskovskoj oblasti Komitet lesnogo hozjajstva Moskovskoj oblasti (Moscow Region Government. Forestry Committee of the Moscow Region): Krasnogorsk, Russia, 2018; p. 154. Available online: https://klh.mosreg. ru/download/document/3613600 (accessed on 28 March 2020).

32. Lesnye Plany Regionov Rossii (Forest Plans of Regions of Russian Federation). Available online: http: //hcvf.wwf.ru/ru/documents_old (accessed on 28 March 2020).

33. Arkhipova, M.V. Variation in forest area on the Central Russian Upland within the last 250 years. Contemp. Probl. Ecol. 2015, 8, 830-837. [CrossRef]

34. Belyaeva, N.G.; Popov, S.Y. 200 years long record of forest cover changes in Vereya Uyezd, Moscow Oblast. Russ. J. For. Sci. 2016, 1, 44-54. (In Russian)

35. Hansen, M.C.; Potapov, P.V.; Moore, R.; Hancher, M.; Turubanova, S.A.; Tyukavina, A.; Thau, D.; Stehman, S.V.; Goetz, S.J.; Loveland, T.R.; et al. High-Resolution Global Maps of 21st-Century Forest Cover Change. Science 2013, 342, 850-853. [CrossRef]

36. Turubanova, S.A.; Krylov, A.M.; Potapov, P.V.; Tyukavina, A.Y. Forest dynamics in eastern Europe (1985-2012) using Landsat data archive. Russ. J. Ecosyst. Ecol. 2017, 2, 1-11. (In Russian) [CrossRef]

37. Osipov, V.V.; Gavrilova, N.K. Agrarnoe Osvoenie I Dinamika Lesistosti. Nechernozemnoj Zony RSFSR (Agricultural Development and Dynamics of Forest Cover of the Non-Chernozem Zone of the RSFSR); Nauka: Moscow, Russia, 1983; pp. 1-108. (In Russian)

38. Government of the Russian Federation. Lesnoj Plan Moskovskoj Oblasti Kniga 2 (Forest Plan of the Moscow Region Book 2); Federal Forestry Agency: Moscow, Russia, 2010; p. 1134. (In Russian)

39. Rysin, L.P.; Abaturov, A.V.; Savel'eva, L.I. Dinamika hvojnyh lesov Podmoskov'ja (Dynamic of Coniferous Forests of Moscow Region); Nauka: Moscow, Russia, 2000; p. 221. (In Russian)

40. Maslov, A.D. Koroed-Tipograf I Usyhanie Elovyh Lesov (Bark Beetle and Drying of Spruce Forests); VNIILM: Moscow, Russia, 2010; p. 138. ISBN 978-5-94219-170-2. (In Russian)

41. Kurnaev, S.F. Osnovnye Tipy Lesa Srednej Chasti Russkoj Ravniny (Main Forest Types of Russian Plain Middle Part); Nauka: Moscow, Russia, 1968; p. 356. (In Russian)

42. Abaturov, A.V.; Vakurov, A.D.; Ilyinskay, S.A. Lesa Zapadnogo Podmoskov'ja (Forests of West Part of Moscow Region); Nauka: Moscow, Russia, 1982; p. 233. (In Russian)

43. Rysin, L.P.; Abaturov, A.V.; Kazantseva, T.N. Lesa Vostochnogo Podmoskov'ja (Forests of East Part of Moscow Region); Nauka: Moscow, Russia, 1979; p. 184. (In Russian)

44. Ilinskaya, S.A.; Matveeva, A.A.; Kazantseva, T.N. Lesa Juzhnogo Podmoskov'ja (Forests of South Part of Moscow Region); Nauka: Moscow, Russia, 1985; p. 231. (In Russian)

45. Rysin, L.P.; Savel'eva, L.I. Kadastry Tipov Lesa I Tipov Lesnyh Biogeocenozov (Cadastres of Forest Types and Types of Forest Biodeosenoses); Tovarishhestvo nauchnyh izdanij KMK: Moscow, Russia, 2007; p. 144. ISBN 978-5-87317-397-6. (In Russian)

46. Thomson, G.; Newman, P. Urban fabrics and urban metabolism-From sustainable to regenerative cities. Resour. Conserv. Recycl. 2018, 132, 218-229. [CrossRef]

47. Girardet, H. Creating Regenerative Cities; Routledge: New York, NY, USA, 2015; ISBN 9780415724463.

48. Zari, M.P. Devising Urban Biodiversity Habitat Provision Goals: Ecosystem Services Analysis. Forests 2019, 10, 391. [CrossRef]

49. Annenskaja, G.N.; Zhuchkova, V.K.; Kalinina, V.R.; Mamaj, I.I.; Nizovcev, V.A.; Hrustaljova, M.A.; Cesel'chuk, J.N. Landshafty Moskovskoj Oblasti I Ih Sovremennoe Sostojanie (Landscapes of the Moscow Region and Their Current State); SGU Publishing: Smolensk, Russia, 1997; p. 299. ISBN 5-88984-011-8.

50. Vagner, B.B.; Manucharjanc, B.O. Geologija, Rel'ef I poleznye Iskopaemye Moskovskogo Regiona. Uchebnoe Posobie Po Kursu «Geografija I Jekologija Moskovskogo Regiona» (Geology, Relief and Minerals of the Moscow region. Textbook for the Course "Geography and Ecology of the Moscow Region"); MGPU: Moscow, Russia, 2003; p. 92. (In Russian)

51. Fick, S.E.; Hijmans, R.J. Worldclim 2: New 1-km spatial resolution climate surfaces for global land areas. Int. J. Climatol. 2017, 37, 4302-4315. [CrossRef] 
52. NASA Jet Propulsion Laboratory (JPL). NASA Shuttle Radar Topography Mission Global 1 arc second V003 Sioux Falls, South Dakota, USA. US Geological Survey. Available online: https://lpdaac.usgs.gov/ (accessed on 1 March 2020).

53. Rivas-Martínez, S.; Penas, A.; Díaz, T.E. Bioclimatic \& Biogeographic Maps of Europe. 2004. Available online: https://www.globalbioclimatics.org/form/bi_med.htm (accessed on 1 March 2020).

54. Klinov, F.Y. Climate Weather and Ecology of Moscow; Russia Federal Service of Hydrometeorology and Environmental Monitoring: Moscow, Russia, 1995; p. 437. (In Russian)

55. Varentsov, M.I.; Samsonov, T.E.; Kislov, A.V.; Konstantinov, P.I. Simulations of Moscow agglomeration heat island within the framework of the regional climate model COSMO-CLM. Vestn. Mosk. Univ. Seriya 5 Geogr. 2017, 6, 25-37. (In Russian)

56. Gribova, S.A.; Isachenko, T.I.; Lavrenko, E.M. Rastitel'nost' Evropejskoj Chasti USSR (The Vegetation of the European Part of USSR); Nauka: Leningrad, Russia, 1980; p. 429. (In Russian)

57. Kurnaev, S.F. Lesorastitel'noe Rajonirovanie SSSR (Forest Zoning of USSR); Nauka: Moscow, Russia, 1973 ; p. 202. (In Russian)

58. Petrov, V.V. New scheme of Moscow region geobotanical zoning. Vestn. Mosk. Univ. Biol. Pochvoved. 1968, 5, 44-49. (In Russian)

59. Ogureeva, G.N.; Buldakova, E.V. Diversity of Forests in the Klinsko-Dmitrovskii Ridge Related to the Landscape Structure of the Territory. Russ. J. For. Sci. 2006, 1, 58-69. (In Russian)

60. Merzlenko, M.D. The oldest planting forests of Moscow region. Priroda 1978, 10, 50-57. (In Russian)

61. Cvetkov, M.A. Izmenenie Lesistosti Evropejskoj Rossii S Konca XVII Stoletija Po 1914 God (Forest Cover Change of European Russia from the End of the XVII Century to 1914); USSR Academy of Sciences Publishing House: Moscow, Russia, 1957; p. 213. (In Russian)

62. Markova, I.A. Sovremennye Problemy Lesovyrashhisvanija (Lesokul'turnoe Proizvodstvo): Uchebnoe Posobie (Modern problems of forest planting (Forest production): Textbook); SPbLTA: Sankt-Peterburg, Russia, 2008; p. 152. (In Russian)

63. Shutov, I.V. (Ed.) Plantacionnoe Lesovodstvo (Plantation Forestry); Polytechnic University Publishing House: Sankt-Peterburg, Russia, 2007; p. 366. (In Russian)

64. Braun-Blanquet, J. Pflanzensoziologie, 3rd ed.; Springer: Wien, Austria; New York, NY, USA, 1964; p. 865.

65. Cherepanov, S.K. Sosudistye Rastenija Rossii I Sopredel'nyh Gosudarstv (Vascular Plants of Russia and Adjacent States (the Former USSR)); World and family-95: Sankt-Peterburg, Russia, 1995; p. 992. (In Russian)

66. Maevskij, P.F. Flora Srednej Polosy Evropejskoj Chasti Rossii, 11 Izdanie (Flora of the European part of Central Russia), 11th ed.; Tovarishhestvo nauchnyh izdanij KMK: Moscow, Russia, 2014; p. 635. ISBN 978-5-87317-958-9. (In Russian)

67. Ignatov, M.S.; Afonina, O.M.; Ignatova, E.A.; Abolina, A.; Akatova, T.V.; Baisheva, E.Z.; Bardunov, L.V.; Baryakina, E.A.; Belkina, O.A.; Bezgodov, A.G.; et al. Check-list of mosses of East Europe and North Asia. Arctoa 2006, 15, 1-130. [CrossRef]

68. Ignatov, M.; Milyutina, I. On Sciuro-hypnum oedipodium and S. curtum (Brachytheciaceae, Bryophyta). Arctoa 2007, 16, 47-61. [CrossRef]

69. Konstantinova, N.A.; Potemkin, A.D.; Shljakov, R.N. Spisok pechenochnikov i antocerotovyh territorii byvshego USSR (List of the hepatics and the anthocerotes of the former USSR). Arctoa 1992, 1, 87-127. (In Russian) [CrossRef]

70. Anuchin, N.P. Lesnaja Taksacija: Uchebnik Dlja VUZov (Forest Taxation: A Textbook for High Schools); Timber Industry: Moscow, Russia, 1982; p. 552. (In Russian)

71. Sörensen, T. A method of establishing groups of equal amplitude in plant sociology based on similarity of species content and its application to analyses of the vegetation on Danish commons. K. Dan. Vidensk. Selsk. Biol. Skr. 1948, 5, 1-34.

72. Chernen'kova, T.V.; Morozova, O.V. Classification and Mapping of Coenotic Diversity of Forests. Contemp. Probl. Ecol. 2017, 10, 738-747. [CrossRef]

73. Winer, B.J.; Donald, R.B.; Kenneth, M.M. Statistical Principles in Experimental Design, 3rd ed.; McGraw-Hill: New York, NY, USA, 1991; p. 1057. ISBN 0070709823.

74. R: A Language and Environment for Statistical Computing; R Foundation for Statistical Computing: Vienna, Austria. Available online: https://www.R-project.org/ (accessed on 1 March 2020). 
75. Oksanen, J.; Blanchet, F.G.; Friendly, M.; Kindt, R.; Legendre, P.; McGlinn, D.; Minchin, P.R.; O’Hara, R.B.; Simpson, G.L.; Solymos, P.; et al. Package 'Vegan'. Community Ecology Package. Available online: https://cran.r-project.org/web/packages/vegan/vegan.pdf (accessed on 15 April 2020).

76. Düll, R. Zeigerwerte von Laub- und Lebermoosen. Scr. Geobot. 1991, 18, 175-214.

77. Ellenberg, H.; Weber, H.E.; Düll, R.; Wirth, V.; Werner, W.; Paulissen, D. Zeigerwerte von Pflanzen in Mitteleuropa. Scr. Geobot. 1991, 18, 1-248.

78. Tichý, L. JUICE, software for vegetation classification. J. Veg. Sci. 2002, 13, 451-453. [CrossRef]

79. Dufrene, M.; Legendre, P. Species assemlages and indicator species: The need for a flexible assymetrical approach. Ecol. Monogr. 1997, 67, 345-366.

80. Chernenkova, T.V.; Kotlov, I.P.; Belyaeva, N.G.; Morozova, O.V.; Suslova, E.G.; Puzachenko, M.Y.; Krenke, A.N. Sustainable forest management tools for the Moscow region. Geogr. Environ. Sustain. Spec. Issues Urban Environ. Geogr. 2019, 4, 35-56. [CrossRef]

81. Peterson, A.T.; Soberón, J.; Pearson, R.G.; Anderson, R.P.; Martínez-Meyer, E.; Nakamura, M.; Araújo, M.B. Ecological Niches and Geographic Distributions (MPB-49); Princeton University Press: Princeton, NJ, USA, 2011; pp. 1-328. ISBN 978-0-691-13686-8.

82. Daru, B.H.; Park, D.S.; Primack, R.B.; Willis, C.G.; Barrington, D.S.; Whitfeld, T.J.S.; Seidler, T.G.; Sweeney, P.W.; Foster, D.R.; Ellison, A.M.; et al. Widespread sampling biases in herbaria revealed from large-scale digitization. New Phytol. 2018, 217, 939-955. [CrossRef]

83. Lissovsky, A.A.; Dudov, S.V.; Obolenskaya, E.V. Advantages and limitations of application of the species distribution modeling methods. 1 A general approach. Zhurnal Obs. Biol. 2020, 81, 123-134. (In Russian)

84. Puzachenko, Y.; Zheltukhin, A.; Sandlerskiy, R. Analyzing space-time dynamics of the ecological niche: A case study with the pine marten (Martes martes) population. Biol. Bull. Rev. 2011, 1, 245-264. (In Russian) [CrossRef]

85. Vermote, E.; Justice, C.; Claverie, M.; Franch, B. Preliminary analysis of the performance of the Landsat 8/OLI land surface reflectance product. Remote Sens. Environ. 2016, 185, 46-56. [CrossRef] [PubMed]

86. Kotlov, I.P.; Puzachenko, J.G. Struktura rel'efa Russkoj ravniny kak landshaftoobrazujushhego faktora (Structure of the relief of Russian Plain as landscape forming factor). In Landshaftnoe Planirovanie: Obshhie Osnovanija, Metodologija, Tehnologija (Landscape Planning: Common Base, Methodology, Technology); Geographical department of Lomonosov Moscow State University: Moscow, Russia, 2006; pp. 166-171. (In Russian)

87. Varlygina, T.I.; Zubakin, V.A.; Nikitsky, N.B.; Sviridov, A.V. (Eds.) Krasnaya Kniga Moskovskoy Oblasti; Red Data Book of Moscow region; PF «Verhov'e»: Moscow region, Russia, 2018; p. 810. (In Russian)

88. Arhipova, M.V.; Zamesova, E.J. Botaniko-gegoraficheskaja harakteristika bassejna r. Jazvicy (Botanical and geographical characteristics of the Yazvica river basin). In Jekosistemy Shirokolistvenno-Hvojnyh Lesov Juzhnogo Podmoskov'ja (Ecosystems of Deciduous Coniferous Forests of the Southern Moscow Region); Kasimov, N.S., Gerasimova, M.I., Ogureeva, G.N., Eds.; Geographical Department of Lomonosov Moscow State University: Moscow, Russia, 2006; pp. 20-49. ISBN 5-85941-156-1. (In Russian)

89. Arkhipova, M.V.; Isachenkova, L.B. The soil and vegetation dynamics in the pine-spruce forest ecosystem (the south-west of Moscow area). Environ. Geosci. 2013, 6, 491-501. (In Russian)

90. Orlov, A.Y. Pochvenno-Ekologicheskie Osnovy Lesovodstva V Yuzhnoj Tajge (Soil-Ecological Basics of Forestry in the Southern Taiga); Nauka: Moscow, Russia, 1991; p. 104. (In Russian)

91. Rubtsov, M.V.; Rybakova, N.A. Dynamics of parcel structure of forest phytocoenoses in regenerating spruce population in boreal birch forests. Russ. J. For. Sci. 2016, 5, 323-331.

92. Nicenko, A.A. Tipologija Melkolistvennyh Lesov Evropejskoj Chasti USSR (Typology of Small-Leaved Forests of the USSR European Part); Publishing House of Leningrad University: Leningrad, Russia, 1972; p. 140. (In Russian)

93. Orlov, A.J.; Koshel'kov, S.P.; Osipov, V.V.; Sokolov, A.A. Tipy Lesnyh Biogeocenozov Juzhnoj Tajgi (Types of Forest Biogeocenoses of the Southern Taiga); Nauka: Moscow, Russia, 1974; p. 226. (In Russian)

94. Tømmerås, B.Å. Skogens naturlige dynamikk. Elementer og prosesser i naturlig skogutvikling. In DN-Rapport; Direktoratet for Naturforvaltning: Trondheim, Norway, 1994; pp. 1-48. ISBN 9788270721399.

95. Ogureeva, G.N.; Miklyaeva, I.M.; Suslova, E.G.; Shvergunova, L.V. (Eds.) Vegetation of Moscow Region (Rastitel'nost' Moskovskoj oblasti); EKOR: Moscow, Russia, 1996; p. 45. (In Russian)

96. Abaturov, J.D.; Zvorykina, K.V.; Il'jushenko, A.F. Tipy Berezovyh Lesov Central'noj Chasti Juzhnoj Tajgi (Types of Birch Forests in the Central Part of Southern Taiga); Nauka: Moscow, Russia, 1982; p. 156. (In Russian) 
97. Il'jushenko, A.F.; Koshel'kov, S.P. Stroenie i produktivnost' drevostoev nekotoryh tipov bereznjakov na suglinistyh pochvah (The structure and productivity of some types birch forest stands on loamy soils). In Lesovodstvennye Issledovanija V Podzone Juzhnoj Tajgi (Forestry Research in the Southern Taiga Subzone); Nauka: Moscow, Russia, 1977; pp. 32-42. (In Russian)

98. Franklin, J.F.; Spies, T.A.; Van Pelt, R.; Carey, A.B.; Thornburgh, D.A.; Berg, D.R.; Lindenmayer, D.B.; Harmon, M.E.; Keeton, W.S.; Shaw, D.C.; et al. Disturbances and structural development of natural forest ecosystems with silvicultural implications, using Douglas-fir forests as an example. For. Ecol. Manag. 2002, 155, 399-423. [CrossRef]

99. Kryshen', A.M. Rastitel'nye Soobshhestva Vyrubok Karelii (Vegetation Communities of Karelia Cuttings); Nauka: Moscow, Russia, 2006; pp. 1-264. ISBN 5-02-03561-8. (In Russian)

100. Tsyganov, D.N. Fitoindikacija Jekologicheskih Rezhimov V Podzone Hvojno-Shirokolistvennyh Lesov (Ecological Regimes Phytoindication in the Coniferous-Deciduous Forest Subzone); Nauka: Moscow, Russia, 1983; pp. 1-183. (In Russian)

101. Ulanova, N.G. Mehanizmy sukcessij rastitel'nosti sploshnyh vyrubok v el'nikah juzhnoj tajgi (Succession mechanisms of clear-cutting in spruce forests of the southern taiga). In Aktual'nye Problemy Geobotaniki. III Vserossijskaja Shkola-Konferencija, 24-28 September 2007; Karel'skij Nauchnyj Centr RAN: Petrozavodsk, Russia; pp. 198-211. (In Russian)

102. Pesterova, O.A.; Tihonova, E.V.; Chernenkova, T.V. Floristicheskoe raznoobrazie iskusstvennykh nasazhdenii podzony khvoino-shirokolistvennykh lesov (na primere iugo-zapada Moskovskoi oblasti) (Floristic diversity of artificial plantations in the subzone of coniferous-deciduous forests (case study south-west of the Moscow region)). Vestnyk VGU Ser. Himiia Biol. Farmatceia 2012, 2, 189-196. (In Russian)

103. Morozova, O.V.; Semenishchenkov, Y.A.; Tikhonova, E.V.; Belyaeva, N.G.; Kozhevnikova, M.V.; Chernenkova, T.V. Nemoral herb spruce forests of the European Russia. Veg. Russ. 2017, 31, 33-58. (In Russian) [CrossRef]

104. Ryzhova, N.V. Features of the biological diversity of spruce forests depending on the ecotope. Aktual'nye Probl. Lesn. Kompleks. 2005, 10, 132-134. (In Russian)

105. Genikova, N.V.; Gnatiuk, E.P.; Kryshen, A.M. Coenoflora of bilberry spruce forests in Eastern Fennoscandia. Bot. Zhurnal 2019, 104, 699-716. (In Russian) [CrossRef]

106. Nagaike, T. Review of plant species diversity in managed forests in Japan. ISRN For. 2012, $2012,629523$. [CrossRef]

107. Spake, R.; Yanou, S.; Yamaura, Y.; Kawamura, K.; Kitayama, K.; Doncaster, C.P. Meta-analysis of management effects on biodiversity in plantation and secondary forests of Japan. Conserv. Sci. Pract. 2019, 1, e14. [CrossRef]

108. Igarashi, T.; Masaki, T.; Nagaike, T.; Tanaka, H. Species richness of the understory woody vegetation in Japanese cedar plantations declines with increasing number of rotations. J. For. Res. 2016, 21, 291-299. [CrossRef]

109. Čepelová, B.; Münzbergová, Z. Factors determining the plant species diversity and species composition in a suburban landscape. Landsc. Urban Plan. 2012, 106, 336-346. [CrossRef]

110. Amrein, D.; Rusterholz, H.-P.; Baur, B. Disturbance of suburban Fagus forests by recreational activities: Effects on soil characteristics, above-ground vegetation and seed bank. Appl. Veg. Sci. 2009, 8, 175-182. [CrossRef]

111. Fabbio, G.; Cantiani, P.; Ferretti, F.; Salvatore, U.D.; Bertini, G.; Becagli, C.; Chiavetta, U.; Marchi, M.; Salvati, L. Sustainable Land Management, Adaptive Silviculture and New Forest Challenges: Evidence from a Latitudinal Gradient in Italy. Sustainability 2018, 10, 2520. [CrossRef]

112. Veinotte, C.; Freedman, B.; Maass, W.; Kirstein, F. Comparison of the ground vegetation in spruce plantations and natural forest in the Greater Fundy Ecosystem, New Brunswick. Can. Field Nat. 2003, 117, 531-540. [CrossRef]

113. Lu, D.; Wang, G.; Yan, Q.; Gao, T.; Zhu, J. Effects of Gap Size and Within-Gap Position on Seedling Growth and Biomass Allocation: Is the Gap Partitioning Hypothesis Applicable to the Temperate Secondary Forest Ecosystems in Northeast China? For. Ecol. Manag. 2018, 429, 351-362. [CrossRef]

114. Chernenkova, T.V.; Morozova, O.V.; Belyaeva, N.G.; Puzachenko, M.Y. Actual organization of forest communities with broad-leaved trees in broad-leaved-coniferous zone (with Moscow region as an example). Veg. Russ. 2018, 33, 107-130. (In Russian) [CrossRef] 
115. Chernenkova, T.V.; Puzachenko, M.Y.; Belyaeva, N.G.; Kotlov, I.P.; Morozova, O.V. Pine Forests in Moscow Oblast: History and Perspectives of Preservation. Russ. J. For. Sci. 2019, 5, 449-464. (In Russian) [CrossRef]

116. Chernen'kova, T.V.; Morozova, O.V.; Puzachenko, M.Y.; Popov, S.Y.; Belyaeva, N.G. Composition and Structure of Spruce Forests of the Southwestern Part of Moscow Oblast. Contemp. Probl. Ecol. 2016, 9, 820-833. [CrossRef]

117. Bielak, K.; Dudzińska, M.; Pretzsch, H. Mixed stands of Scots pine (Pinus sylvestris L.) and Norway spruce (Picea abies (L.) Karst) can be more productive than monocultures. Evidence from over 100 years of observation of long-term experiments. For. Syst. 2014, 23, 573-589. [CrossRef]

118. Pukkala, T.; Vettenranta, J.; Kolström, T.; Miina, J. Productivity of mixed stands of Pinus sylvestris and Picea abies. Scand. J. For. Res. 1994, 9, 143-153. [CrossRef]

119. Bertness, M.; Callaway, R.M. Positive interactions in communities. Trends Ecol. Evol. 1994, 9, $191-193$. [CrossRef]

120. Ammer, C.; Fichtner, A.; Fischer, A.; Gossner, M.M.; Meyer, P.; Seidl, R.; Thomas, F.M.; Annighöfer, P.; Kreyling, J.; Ohse, B.; et al. Key Ecological Research Questions for Central European Forests. Basic Appl. Ecol. 2018, 32, 3-25. [CrossRef]

(C) 2020 by the authors. Licensee MDPI, Basel, Switzerland. This article is an open access article distributed under the terms and conditions of the Creative Commons Attribution (CC BY) license (http://creativecommons.org/licenses/by/4.0/). 